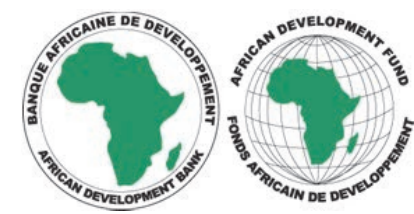

WIDER Working Paper 2014/076

\title{
The evolution of Vietnamese industry
}

Nguyen Thi Tue Anh, ${ }^{1}$ Luu Minh Duc, ${ }^{1}$ and Trinh Duc Chieu ${ }^{2}$

April 2014 
Abstract: The transfer from an import-substitution to an export-orientation strategy has been in effect in Vietnam since the reform process, Doi Moi, necessitating the reformulation of macroeconomic, trading and sectoral policies. As a result, the industry sector has experienced gradual growth as the country's economy is becoming more open and gaining deeper integration with regional and the world economies, as exemplified by membership in the ASEAN Free Trade Area (1995) and World Trade Organization (2006). To support this integration process, the structure of the industrial sector has been changed to more appropriate since the Doi Moi.

Many export processing zones, industrial zones and economic zones have been set up to attract the interest of multi-sectors, including foreign and non-state investors. Consequently, the capacity, output and productivity of the industrial sector have improved considerably. But certain policy issues also arose during the industrial development process. These can be summarized into three main problems: minimal contribution from current policies to improving competitiveness, policy failure to encourage firm restructuring, and lack of a well-coordinated framework for industrial policy.

Keywords: industry, evolution, policy, productivity, Vietnam JEL classification: L52

Acknowledgements: This paper is one of a series of studies on industrial development in Africa produced in collaboration between the Africa Growth Initiative at Brookings, the African Development Bank (AfDB), and UNU-WIDER under their joint project 'Learning to Compete' (L2C).

Acronyms: given at the end of the document.

\footnotetext{
${ }_{1}^{1}$ Central Institute for Economic Management, Hanoi; ${ }^{2}$ Department of Enterprise Reform and Development, CIEM, Hanoi

This study has been prepared within the UNU-WIDER project 'Learning to Compete: Accelerating Industrial Development in Africa', directed by John Page.

Copyright (C) UNU-WIDER 2014

ISSN 1798-7237 ISBN 978-92-9230-797-4

Typescript prepared by Liisa Roponen at UNU-WIDER.

UNU-WIDER gratefully acknowledges the financial contributions to the research programme from the governments of Denmark, Finland, Sweden, and the United Kingdom.

The World Institute for Development Economics Research (WIDER) was established by the United Nations University (UNU) as its first research and training centre and started work in Helsinki, Finland in 1985. The Institute undertakes applied research and policy analysis on structural changes affecting the developing and transitional economies, provides a forum for the advocacy of policies leading to robust, equitable and environmentally sustainable growth, and promotes capacity strengthening and training in the field of economic, and social policy-making. Work is carried out by staff researchers and visiting scholars in Helsinki and through networks of collaborating scholars and institutions around the world.
}

UNU-WIDER, Katajanokanlaituri 6 B, 00160 Helsinki, Finland, wider.unu.edu

The views expressed in this publication are those of the author(s). Publication does not imply endorsement by the Institute or the United Nations University, nor by the programme/project sponsors, of any of the views expressed. 


\section{Introduction}

One of the most important policy decisions that Vietnam made in the Doi Moi process was the shift from a strategy of import-substitution to one of export-orientation strategy. Obviously, Vietnamese policy-makers wanted to avoid the failure of the Latin American economies and to learn from the success of the industrialized nations and newly industrialized economies (NIEs) of East Asia, the renowned 'flying geese'. As a result, during the past decade, Vietnam industrial output grew at an average annual rate at 15.2 per cent and total annual exports increased 18.1 per cent (GSO 2011).

Undeniably, the industrial and export performance has been the key driver of this economic growth, radically changing the country over the past two decades ago. Vietnam also experienced the widely increasing role of the dynamic foreign direct investment (FDI) and the private sector in manufacturing and exporting activities, in contrast to the earlier monopolistic behaviour and inefficiency of the centrally-planned state-owned enterprises (SOEs). Today, the remaining SOEs have become more active and competitive exporters, certainly a reflection of Vietnam's learning process and spill-over effects at both the country and cross-sector levels. Thus, it could be quite interesting and helpful if low-income countries were able to benefit from Vietnam's lessons and experience of achieving growth through industrial and export expansion.

However a number of questions can be raised with regard to Vietnam's industrial development: What is the role of industry in general, and manufacturing in particular, in the country's economic development? Are the industrialization policies consistent and clearly defined for the short term and long term? How does foreign investment contribute to industrialization in Vietnam? And more important, what is the role of the private sector in industrialization in the context of the government still firmly upholding the dominance of SOEs?

Industrial growth in Vietnam is based on its export-oriented policy. The country gained World Trade Organization (WTO) membership in 2007, and with a highly open economy, its total export value had reached 70.6 per cent of GDP by 2010 . The momentum of the industry indicates that Vietnam has been on right track with regard to its industrial policy for the last 20 years. However, it is not certain that exporting firms have gained efficiency through exports. Thus, studying this subject should contribute to the industrial policy debate in Vietnam as the country's economy continues to struggle with the issue of how to raise the quality and competitiveness of exports and capacity of local exporters.

This scoping paper is structured in four section in addition to the introduction. Evolution of the industry describes the changes and historical episodes of the nation's industrial growth from 1965 to 1975 when Vietnam was united, adopting a central-planning economy. The Doi Moi process started in 1986 with open and market economy policies and the country joined the W'TO in 2007. The second section analyses the structure of the industrial sector by sectoral composition, geographical distribution, ownership and industrial products, including the 'sunrise' and 'sunset' industries. The industrial policy framework is discussed in section three, outlining macroeconomic policy choices, trade policies and institutional and regulatory framework analysis. The fourth section analyses the industrial productivity patterns, with regard to output and turnover per worker by industrial sectors and ownership and firm sizes. Last but not least, the final section summarizes the most important outputs of the study that support emerging policies issues, and the ensuring solutions and adjustments. 


\begin{tabular}{|c|c|c|c|}
\hline $1965-75$ & 1976-85 & 1986-2005 & 2006 to present \\
\hline \multicolumn{4}{|c|}{ Policy plan } \\
\hline \multirow[t]{2}{*}{$\begin{array}{l}\text { War in the south and the socialist } \\
\text { industrialization in the north }\end{array}$} & $\begin{array}{l}\text { Socialist industrialization in the centrally } \\
\text { planning economy }\end{array}$ & $\begin{array}{l}\text { Doi Moi process and industrialization in the } \\
\text { transition towards market-oriented and open } \\
\text { economy }\end{array}$ & $\begin{array}{l}\text { Industrialization in post-WTO entry period } \\
\text { and economic restructuring issues }\end{array}$ \\
\hline & \multicolumn{2}{|c|}{ Objectives and key industries } & \\
\hline $\begin{array}{l}\text { To prioritize the development of } \\
\text { heavy industry; the industry sector } \\
\text { was exclusively led by the SOEs }\end{array}$ & $\begin{array}{l}\text { To overcome consequences of the war } \\
\text { and restore the country's infrastructure } \\
\text { network and industrial bases, including } \\
\text { the state entrepreneurship }\end{array}$ & $\begin{array}{l}\text { 1991-95: Development of prioritized sectors: } \\
\text { heavy industry (cement, steel) and natural } \\
\text { resource-based industries (oil exploitation } \\
\text { and mining). Manufacturing sectors for the }\end{array}$ & $\begin{array}{l}\text { Policies of boosting economic structural } \\
\text { change towards industrialization and } \\
\text { modernization; more export-oriented: } \\
\text { continuation of earlier priorities, but with }\end{array}$ \\
\hline \multirow[t]{2}{*}{$\begin{array}{l}\text { Shift from heavy industry (1961- } \\
65) \text { to fighting industry and } \\
\text { agriculture (1966-73) }\end{array}$} & To concentrate on heavy industry & $\begin{array}{l}\text { domestic demand (food stuff industries) } \\
\text { and export of manufactured labour-intensive } \\
\text { products at the same time }\end{array}$ & greater selection \\
\hline & & $\begin{array}{l}\text { 1996-2000: Continuation of earlier priorities, } \\
\text { but with greater selection Development of } \\
\text { light export-oriented industries (textiles and } \\
\text { garments, footwear, paper production) }\end{array}$ & \\
\hline
\end{tabular}

To continue the north's interrupted First 5-Yr Plan (1960-65) by incorporating the nationwide Second 5-Yr Plan (1976-80)

Planning economy, no market-based price mechanism
+ Protectionism for some certain industries

through tariff and non-tariff instruments such as quota and import/export duties and export subsidies

+ Encourage private businesses and foreign-owned enterprises with Law on Foreign Investment in 1987 and Company Law in 1991

+ Implementation of Public. Investment Programme (1996-2000)

+ Equitization of SOEs and building of state economic groups to enhance the competitiveness of the SOE sector in the industry

+ Development of IZs, EPZs to encourage export production (1996-2001)
+ Specified many leading industries for development. Strategies approved fo about 39 industries (see Appendix)

+ Promotion of technology transfer via foreign investment

+ Continued export production of manufactured products

+ Promulgation of Law on Investment and Law on enterprise to compliance with WTO commitments

+ Removal of non-tariff, but application of export tax rate at $0 \%$ continued for most export products to motivate the export activities 
Table 1: Vietnam's industrial policy matrix (continued)

Table 1 continues

1965-75

1976-85

$1986-2005$

2006 to present

The First 5-Yr Plan 1961-65 was High growth of heavy industry, but

Evaluation

disrupted in 1964 because of US bureaucratic and unprofitable state-owned

air strikes in the north enterprises in industrial production; low

large-scale constructions

industrial infrastructure,

labour productivity, material and

transportation systems were

severely damaged, shortage of

technological shortfalls, and insufficient

availability of food and consumer goods

labour force due to the war

-'Picking-winner approach; Dualistic

structure of Vietnam's industrial sector

- Export structure was changed towards

increasing the share of manufactured

products; the main exporting products were

still mining and crude oil

- Inefficient SOE sector in industrial

production; low industrial labour productivity
The import-substitution sectors failed to

grow up and to provide sufficient supply

for other downstream industries, including export-oriented ones

The export-oriented sector had to rely on inputs from import

Desired spill-over impacts from FDI,

particularly via technology transfer and

linkages with domestic enterprises, were

virtually non-existent

Industrial policies failed to facilitate firms activities sufficiently

Remaining inefficient SOEs, including

state economic groups

The industrial policy focused too much on specific sectors and products, not on

improving competitiveness of enterprises

Source: Vietnam's Five-year Socioeconomic Development Plans covering the 5-year periods from 1961 to 2015, as approved by the National Assembly. 
The evolution of Vietnam's industrial process can be divided into four stages with main characteristics as illustrated in the policy matrix below.

\subsection{Socialist industrialization in the centrally-planned economy, 1965-85}

Although gaining independence in 1945, Vietnam was at war with the French until 1954, when the country was split into two warring parts, each with a different political and economic ideology. In such a context, socialist industrialization was adopted in the north to support the effort to re-unify the country after the American intervention in the south dating back to 1964.

At this time, Vietnam's economy was characterized by village-based subsistence agriculture. The occupying French government had developed agriculture production (rice and rubber) in the south and manufacturing (in fact, mainly coal-mining for export) in the north. After 80 years of colonialism and war, the country was severely damaged: infrastructure was minimal, the population poor and mainly illiterate, and entrepreneurship limited. Under the socialist model, economy was totally controlled by the state. Furthermore, in the context of land reform in the rural areas and the collective corporatization process, the private sector had no place in industrial production in the north.

All technical and scientific research activities were concentrated on servicing heavy industry and the war effort. Remarkably, most of the industrial development in this period was achieved through foreign assistance from Vietnam's socialist allies (China, the Soviet Union, and other East-bloc nations).

Vietnam's industrial policy of this time was articulated in the country's First Five-Year Plan (196165) which prioritized heavy industry. The plan, however, was disrupted in 1964, when the US started air strikes in the north, preventing progress in heavy industry and tilting what economic activity remained to light industry and agriculture.

The US bombings during 1965-72 destroyed all six industrial cities of the north as well as most of the provincial and district towns. All power stations, railway lines, roads, bridges, and sea and inland ports were seriously damaged, interrupting transportation routes and energy supplies, including power and petroleum. Consequently, the distribution of raw material and consumer goods was badly affected and delayed all large-scale construction. More importantly, since the vast majority of the labour force was employed in the war effort, the rest of the economy was constrained by severe labour shortages.

In the post-war period (1976-85), Vietnam faced three major economic challenges: (i) to repair the destructive consequences of the war and restore the country's infrastructure network and industrial bases, including state entrepreneurship; (ii) to adopt an unified and a centrally planned system for the whole country; and (iii) to continue the north's interrupted First Five-Year Plan (1960-65) to incorporate a Second Five-Year Plan (1976-80) as the nationwide strategy to achieve the ambitious target of building Vietnam into a socialist economy within 20 years.

During this period, industrial planning was the central function of the state's economic administration, with the government defining input and output levels for the entire economy. There was no market-based price mechanism, as open trade and private entrepreneurship were not 
officially recognized. Without a company law in existence, all industrial producers and traders were state-owned enterprises, governed directly by the ministries and provincial authorities, which made these highly bureaucratic and unprofitable.

More than 80 per cent of national income in the early 1980s came from the agricultural sector which was dominated by village-level 'collectives'. Growth of the agricultural and light industrial sectors outpaced that of heavy industry, despite its larger share of the government budget. Based on the scarce statistics that were (irregularly) published, industrial production increased at an annual rate of 9.5 per cent over 1981-85 and income per capita 6.4 per cent per annum. But the economy was characterized by small-scale production, low-labour productivity, high unemployment, material and technological shortfalls, and insufficient availability of food and consumer goods. During the years 1976-85, when the economy faced a slowdown, national income was said to have met 80-90 per cent of the needs, and the inflation throughout the period remained in double-digits. By 1985-86, Vietnam was on the brink of a socioeconomic crisis.

\subsection{The transition from centrally-planned to market economy, 1986-2005}

Against this backdrop, the government launched a comprehensive reform, ${ }^{1}$ called Doi Moi (renovation) in December 1986. Doi Moi was engineered to transform the economy from a centralplanning subsidy economy towards a 'socialist-oriented market economy' that would combine state intervention (mostly at the planning phase) and free-market incentives and rules, where private businesses and foreign-owned enterprises were to be encouraged. ${ }^{2}$

During the era steered by the Third Five-Year Plan (1986-90), annual production of steel increased 8 per cent, cement 11 per cent, electricity 11.1 per cent, and zinc 10 per cent. New industries emerged, especially with the discovery of oil (made possible through joint ventures between the state and foreign oil companies) which increased government revenues and accounted for the greatest share of Vietnamese exports. In the space of a few years (1989-90), Vietnam transformed from a foodinsufficient country to become the world's second largest exporter of rice.

The Doi Moi process strongly influenced the development of Vietnam's industry. During 1991-95, average annual industry growth rate reached 13.7 per cent, a pace that was maintained in later years. Remarkable growth was evident in all industrial products, for example, coal exploration topped 26.39 million tons (or 5.7 times higher than in 1990); electricity (5.24 times over the 1990 level) cement (ten times), and assembled televisions (17.6 times).

As Figure 2 shows, over the 1991-2006 period GDP expanded, on average, at an annual rate of 7.59 per cent. 3 In 2005, GDP per capita was US\$640 (compared to US\$200 in 1990). The savings ratio in

1 The Doi Moi process was announced by the Vietnam Communist Party at its 6th Party Congress in 1986.

2 This transition entailed several major changes in economic policy, including: (i) developing a multi-sectoral economy with official recognition of the private sector; (ii) removing subsidies and planning mechanisms, forcing state enterprises to become self-reliant; (iii) abolishing price controls for consumption goods. More importantly, industrial production was focused on three immediate needs, including food, consumer goods and export goods and (iv) since exportorientation was viewed as an important strategy for economic growth, foreign investment was encouraged.

3 Corresponding figures for the 5-year periods: 8.2 per cent (1991-95); 7.0 per cent (1996-2000); and 7.5 per cent (2001-06). 
GDP increased from 14.36 per cent (1990) to 35.58 per cent (2004). And the portion of the population below the poverty line dropped from 69 per cent (1990) to 28.9 per cent (2005).

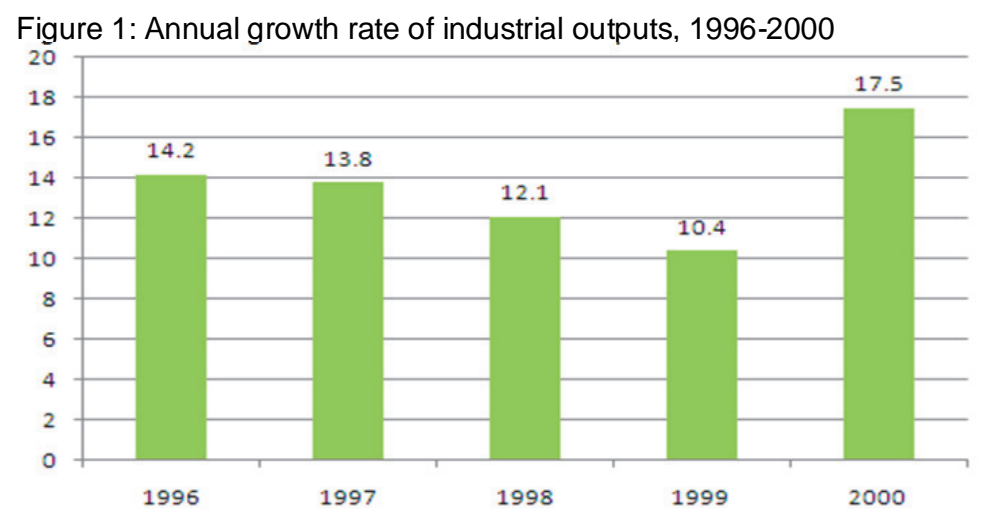

Source: GSO.

Figure 2: Vietnam's GDP annual growth rates, 1991-2005

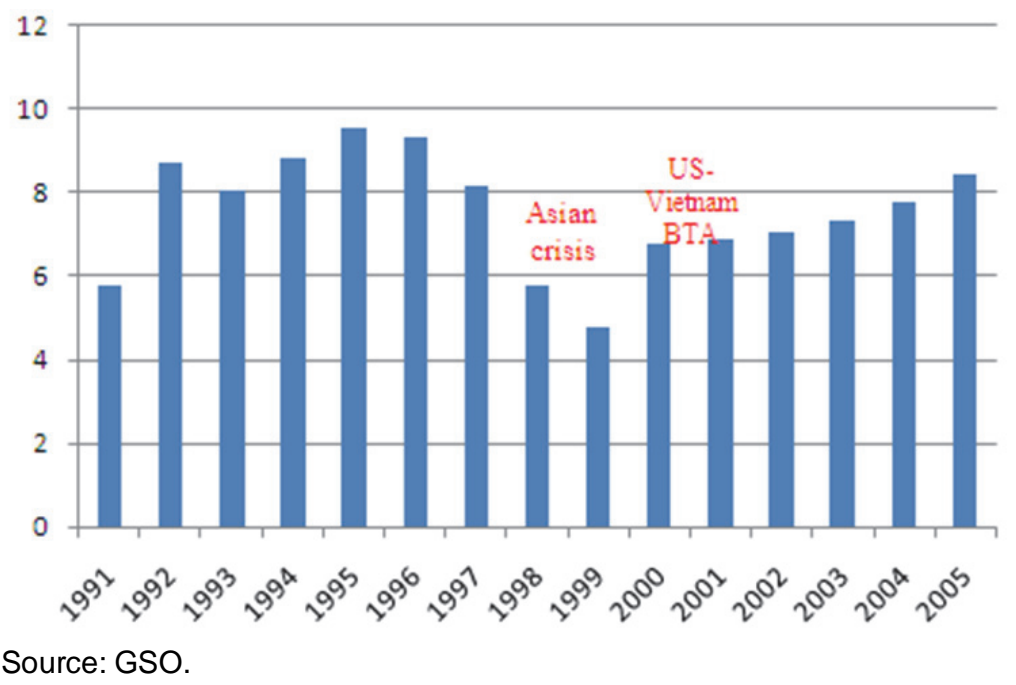

Dramatic changes were also observed in the structure of the economy. The proportion of agriculture in GDP sharply declined from 46.3 per cent (1988) to 20.9 per cent (2005), while the share of industry increased from 21.6 per cent to 41 per cent, and services from 33.1 per cent to 38.1 per cent during the same period. Labour, however, remained relatively unproductive. Agricultural employment accounted for 73.02 per cent of total labour in 1990, dropping to 56.8 per cent by 2005 , while industry and construction sector increased from 12.1 to 17.9 per cent, and services from 19.7 to 25.3 per cent.

Over 48,000 private businesses were established during 1990-99, and this number rose quickly once the Enterprise Law was enacted (1999). For example, 45,691 new companies were registered in 2006 alone, bringing the total number of private-sector firms to over 200,000. The results from the enterprise census show that of the total net business sector turnover in 2006, private enterprises 
accounted for 41.96 per cent, foreign firms 22.22 per cent and SOEs 35.82 per cent. Thanks to the reform of SOEs, their numbers dropped from 12,084 enterprises (1990) to 2,980 exclusively stateowned enterprises and 670 with 50 per cent state-ownership (2005).

\subsection{Industrialization following WTO accession, 2007 to present}

Vietnam's integration deeper into the world economy was promoted by not only the bilateral trade agreements (BTA) and free trade agreements (FTA) signed with other countries but also by joining the WTO in 2007. In general, WTO membership has had a positive impact on the economy, and Vietnam has benefited from the high growth of major trade partners such as US and China, and particularly the high economic momentum of the East Asian countries (CIEM 2010a). While Vietnam's foreign trade in 1986 was valued at US $\$ 1.0$ billion and US $\$ 5.10$ billion in 1990, it was in excess of US $\$ 211.2$ billion in 2011. Exports totalled US $\$ 96.3$ billion, more than 79 per cent of GDP. But global integration introduces contrary effects on the economy: as exports rely heavily on imported inputs, increases on the world market in production material costs had a severe impact, generating inflationary pressures and dampening growth. Exports are also negatively affected by the recession in many trade partners. On the other hand, increases in the price of crude oil and foodVietnam's major exports-had a positive effect on exports, and subsequently growth. Furthermore, as the result of its WTO membership, Vietnam should have opportunities to expand exports to new markets.

An important point to note is that as a result of WTO membership, and in particular as a result of the 2007 and 2011 global economic crises, many industrial sectors in Vietnam faced the adverse effects of the international markets, with almost all sectors declining after 2006. The labour-intensive industries were hit particularly hard, and growth in processing industries declined from 12.37 per cent in 2007 to 2.76 in 2009, partly because of pressure from imports after several tariff lines in this group were cut in compliance to WTO commitments. At the same time, export sectors suffered from declining demands due to the global crisis. According to the CIEM report (2010), the sectors using agro-products as input (food-processing, beverages) suffered the most. A similar trend in output growth was observed in capital-intensive sectors such as paper, chemicals, metal and metal products.

\section{The current structure of the industrial sector}

\subsection{Sectoral composition}

It is obvious that the share of the manufacturing sector in industry has expanded. The processing and manufacturing sector accounted for 81.2 per cent in 2001, but had risen to 86.5 per cent a decade later. In contrast, the share of mining has decreased from 13.1 to 8.45 per cent (Figure 3, see Appendix for a detailed breakdown).

Crude oil and gas made up the greatest share of the mining sector, which nevertheless declined gradually between 2000-10. Exports have been reduced since 2010 to supply crude oil to Vietnam's Dung Quat refinery, reducing oil export values from US $\$ 8.5$ million in 2007 to US $\$ 5$ million in 2010. Coal mining, on the other hand, has grown strongly, doubling its share from 1.2 per cent to 1.97 per cent of the total. 
Table 2: Structure of production outputs of industrial subsectors and share of industrial subsectors in GDP, 2001-11

\begin{tabular}{|c|c|c|c|c|c|c|c|}
\hline & 2001 & 2005 & 2006 & 2007 & 2008 & 2009 & 2010 \\
\hline Share of industrial sectors in GDP (\%) & 32.32 & 34.55 & 34.91 & 34.39 & 31.13 & 33.59 & 33.55 \\
\hline \multicolumn{8}{|l|}{ Of which: } \\
\hline Mining and quarrying & 9.21 & 10.59 & 10.23 & 9.77 & 9.87 & 9.97 & 11.04 \\
\hline Manufacturing & 19.78 & 20.51 & 21.25 & 21.13 & 21.26 & 20.09 & 19.28 \\
\hline Electricity, gas and water & 3.33 & 3.45 & 3.43 & 3.49 & 3.18 & 3.53 & 3.23 \\
\hline \multicolumn{8}{|c|}{ Structure of production outputs of industrial subsectors (\%) } \\
\hline Mining and quarrying & 13.1 & 11.22 & 10.3 & 9.66 & 9.86 & 9.23 & 8.45 \\
\hline Manufacturing & 81.2 & 82.80 & 84.2 & 84.95 & 85.14 & 85.32 & 86.49 \\
\hline Electricity, gas and water & 5.7 & 5.98 & 5.5 & 5.39 & 5.0 & 5.55 & 5.06 \\
\hline Total (\%) & 100.0 & 100.0 & 100.0 & 100.0 & 100.0 & 100.0 & 100.0 \\
\hline $\begin{array}{l}\text { Share of industrial employment in total } \\
\text { employment (\%) }\end{array}$ & 9.67 & 13.5 & 14.4 & 14.5 & 13.8 & 14.4 & 14.4 \\
\hline Mining and quarrying & 0.6 & 0.8 & 0.9 & 0.6 & 0.6 & 0.6 & 0.6 \\
\hline Manufacturing & 8.8 & 12.3 & 13.1 & 13.5 & 12.9 & 13.5 & 13.5 \\
\hline Electricity, gas and water & 2.3 & 0.4 & 0.4 & 0.4 & 0.3 & 0.3 & 0.3 \\
\hline \multicolumn{8}{|c|}{ Structure of industrial employment by subsectors (\%) } \\
\hline Mining and quarrying & 13.1 & 11.22 & 10.3 & 9.66 & 9.86 & 9.23 & 8.45 \\
\hline Manufacturing & 81.2 & 82.80 & 84.2 & 84.95 & 85.14 & 85.32 & 86.49 \\
\hline Electricity, gas and water & 5.7 & 5.98 & 5.5 & 5.39 & 5.0 & 5.55 & 5.06 \\
\hline Total (\%) & 100.0 & 100.0 & 100.0 & 100.0 & 100.0 & 100.0 & 100.0 \\
\hline
\end{tabular}

Source: GSO.

\subsection{Geographical distribution}

Vietnamese industrial production is concentrated in the southeast and around the Red River Delta, particularly in the proximity of Hanoi and Ho Chi Minh City. The southeast still accounts for half of the country's industrial production, of which Ho Chi Minh City produced 24.2 per cent in 2005 and 20.12 per cent in 2010. The regional share of the Red River Delta rose from 21.7 to 24.96 per cent, in which the share of Hanoi, the capital, increased from 7.8 to 8.07 per cent. These two regions alone account for 74 per cent of the nation's industrial output. Relatively substantial increases are also evident in the coastal central region (from 7 per cent to 9.35) and the Mekong River Delta (from 8.8 per cent to 10.05) over the same period.

The spatial distribution of industry has been driven by the introduction of such development policies as the export processing zones (EPZs), economic zones (EZs), High-tech zones and IZs (industrial zones) that have been launched in the country since the early 1990s. Currently, there are 283 IZs encompassing a land area of 76,000 ha, of which 61 per cent is occupied (MPI 2012). Similar to the distribution of industry, 60 per cent of IZs are located in the southeast (32.1 per cent) and Red River Delta (27.9 per cent) (see Appendix). 
Table 3: Geographical distribution of industrial production, 2005-09 (i\%)

\begin{tabular}{lrrrrrr}
\hline & 2005 & 2006 & 2007 & 2008 & 2009 & 2010 \\
\hline Whole country & 100.00 & 100.00 & 100.00 & 100.00 & 100.00 & 100.00 \\
Red River Delta & 21.66 & 22.53 & 24.48 & 24.73 & 24.12 & 23.96 \\
Hà Nội & 7.77 & 7.66 & 7.91 & 9.08 & 8.72 & 8.07 \\
Hải Phòng & 2.55 & 2.73 & 2.95 & 3.10 & 2.81 & 2.58 \\
Northern midlands and mountain areas & 2.49 & 2.51 & 2.66 & 2.89 & 2.71 & 2.89 \\
North central area and central coastal area & 7.00 & 6.65 & 6.49 & 6.60 & 7.19 & 9.35 \\
Central highlands & 0.73 & 0.75 & 0.75 & 0.78 & 0.78 & 0.77 \\
South East & 55.65 & 55.29 & 53.18 & 52.24 & 52.20 & 50.04 \\
Bình Dương & 8.06 & 8.37 & 8.91 & 9.25 & 8.86 & 8.71 \\
Đồng Nai & 10.60 & 11.82 & 10.96 & 10.69 & 10.33 & 10.59 \\
Bà Rịa - Vũng Tàu & 12.00 & 11.19 & 10.11 & 10.01 & 9.88 & 9.50 \\
TP.Hồ Chí Minh & 24.23 & 23.14 & 22.36 & 21.37 & 22.18 & 20.12 \\
Mekong River Delta & 8.84 & 8.89 & 9.23 & 9.85 & 9.97 & 10.05 \\
Not identified & 3.63 & 3.38 & 3.21 & 2.91 & 3.03 & 2.94 \\
\hline
\end{tabular}

Source: GSO.

\subsection{Industrial structure by ownership}

Prior to the launch of the Doi Moi reform, industry was controlled by the state-owned sector but is currently dominated by FDI and non-state sectors. This is largely evidenced by the difference in the growth rate of the three sectors. Industrial gross output of the state sector grew 6 per cent in 2006, reaching on average a rate of 7.8 per cent during 2008 to 2011 while corresponding figures were 26 per cent and 14.65 per cent for the non-state sector and 20 per cent and 14.68 per cent for the FDI sector, respectively.

Due to rapid growth, the share of the FDI sector increased from 37.3 to 41.8 per cent during 200511 , which could indicate that national industry relied on external resources and capacity. The output share of non-state sector expanding quickly (29 per cent in 2005 to 35 per cent by 2008), remaining relatively stable until 2011. In contrast, the share of the state sector in total industrial gross output dropped from 33.7 per cent to only 22.8 per cent over the same period.

Statistics show that the strength of manufacturing is derived from FDI and the domestic non-state sector. Private businesses have focused on processing (garments, leather, food and beverages, wood and paper); chemicals and metallurgy (rubber, oil refinery, steel-making); and engineering and consumer goods (electronics, computers, automobiles, furniture, recycling). There may be two reasons for this. First, the private sector is yet to be allowed to invest in certain sectors such as crude oil exploration, energy and some other utility industries. And, second, most private firms are young with capital constraints and are thus unable to compete with the better-advantaged SOEs.

Within the FDI sector, manufacturing has been the largest and fastest-growing sector. It is well represented in mineral mining; yet due to diminishing oil production, this sector has seen negative growth since 2005 (Tables 4 and 5; see appendix for more details). 
Table 4: Structure of industrial gross output by ownership and subsectors at the 1994 price (\%)

\begin{tabular}{llrcccc}
\hline & Total & $\begin{array}{c}\text { Mining and } \\
\text { quarrying }\end{array}$ & Manufacturing & $\begin{array}{c}\text { Electricity, gas, } \\
\text { steam \& air } \\
\text { conditioning }\end{array}$ & $\begin{array}{c}\text { Water supply, sewerage, } \\
\text { waste management \& } \\
\text { remediation activities }\end{array}$ \\
\hline Total & & 100.0 & 100.0 & 100.0 & 100.0 & 100.0 \\
2005 (2006) State & 33.7 & 20.1 & 30.7 & 95.4 & 81.3 \\
& Non-state & 29.0 & 8.0 & 33.2 & 1.8 & 14.6 \\
& FDI & 37.3 & 72.0 & 36.1 & 2.8 & 4.1 \\
2088 & State & 24.7 & 26.9 & 20.2 & 94.8 & 77.1 \\
& Non-state & 35.0 & 11.7 & 38.4 & 2.9 & 20.7 \\
& FDI & 40.3 & 61.5 & 41.4 & 2.3 & 2.3 \\
& State & 23.8 & 23.9 & 19.2 & 94.7 & 71.2 \\
& Non-state & 35.6 & 14.0 & 39.0 & 2.8 & 21.9 \\
& FDI & 40.7 & 62.1 & 41.9 & 2.6 & 67.9 \\
& State & 23.3 & 26.68 & 18.57 & 94.98 & 25.7 \\
& Non-state & 35.5 & 15.48 & 38.55 & 3.02 & 6.61 \\
& FDI & 41.2 & 57.85 & 42.88 & 2.0 & 66.25 \\
& State & 22.8 & 26.57 & 18.14 & 95.11 & 27.33 \\
& Non-state & 35.4 & 16.47 & 38.23 & 3.08 & 6.41 \\
\hline
\end{tabular}

Source: Computed by the authors based on data from GSO.

Table 5: Growth and share of industrial gross output and subsectors by ownership at 1994 prices (\%)

\begin{tabular}{|c|c|c|c|c|c|c|c|c|c|c|}
\hline & & \multicolumn{5}{|c|}{ Growth } & \multicolumn{4}{|c|}{ Share } \\
\hline & & Total & Mining & Manuf. & Electricity & Water & Mining & Manuf. & Electricity & Water \\
\hline \multicolumn{2}{|c|}{$2005 / 2006$ Total } & 17 & -1 & 19 & 12 & 24 & 9 & 85 & 6 & 0 \\
\hline & State & 6 & 12 & 4 & 12 & 20 & 6 & 77 & 16 & 1 \\
\hline & Non-state & 26 & 14 & 26 & 54,1 & 40 & 3 & 97 & 0 & 0 \\
\hline & FDI & 20 & -7 & 26 & -3 & 44 & 18 & 82 & 0 & 0 \\
\hline \multirow[t]{4}{*}{2008} & Total & 14 & -3 & 15 & 12 & 22 & 6 & 89 & 5 & 1 \\
\hline & State & 3 & 2 & 0 & 11 & 17 & 6 & 73 & 20 & 2 \\
\hline & Non-state & 20 & 17 & 20 & 56 & 44 & 2 & 97 & 0 & 0 \\
\hline & FDI & 17 & -8 & 20 & 4 & 12 & 8 & 91 & 0 & 0 \\
\hline \multirow[t]{4}{*}{2009} & Total & 9 & 9 & 8 & 14 & 10 & 6 & 88 & 5 & 1 \\
\hline & State & 5 & -3 & 3 & 13 & 2 & 6 & 71 & 21 & 2 \\
\hline & Non-state & 10 & 31 & 10 & 8 & 17 & 2 & 97 & 0 & 0 \\
\hline & FDI & 9 & 10 & 9 & 25 & 235 & 9 & 91 & 0 & 0 \\
\hline \multirow[t]{4}{*}{2010} & Total & 16 & 1 & 17 & 14 & 16 & 5 & 89 & 5 & 1 \\
\hline & State & 13 & 13 & 13 & 15 & 10 & 6 & 71 & 22 & 2 \\
\hline & Non-state & 15 & 12 & 15 & 24 & 36 & 2 & 97 & 0 & 0 \\
\hline & FDI & 17 & -6 & 20 & -11 & 11 & 7 & 93 & 0 & 0 \\
\hline \multirow[t]{4}{*}{2011} & Total & 14 & 3 & 14 & 11 & 13 & 4 & 90 & 5 & 1 \\
\hline & State & 11 & 2 & 12 & 12 & 10 & 5 & 72 & 22 & 2 \\
\hline & Non-state & 13 & 9 & 13 & 13 & 20 & 2 & 97 & 0 & 0 \\
\hline & FDI & 15 & 1 & 16 & 1 & 9 & 6 & 94 & 0 & 0 \\
\hline
\end{tabular}

Note: Subsectors include: mining and quarrying; manufacturing; electricity, gas, steam and air conditioning supply; Water supply; sewerage, waste management and remediation activities.

Source: Computed by the authors based on data from GSO. 


\section{Sunrise and sunset industries}

'Sunrise' industries are emerging or fast-growing sectors that will generate growth, replacing the mature, declining 'sunset' industries. Although these will still continue to play an important role, their languishing profitability, stagnant productivity, and declining competitiveness will be taken over by new sectors. Table 6 lists the top 10 industries with the highest share in total industrial output. The sunset or sunrise industries of the recent 5-year period will be determined on the basis of the latest and fastest growth criteria. Several other indicators are also taken into account in grouping Vietnam's sunrise and sunset industries. These include: (i) the increasing number of enterprises in the field (ii) production outputs; (iii) annual export value; and (iv) industrial-policy orientation.

Table 6: Top 10 sub-industries with the highest share in total industrial output (at current prices, \%).

\begin{tabular}{lrlrlr}
\hline \multicolumn{1}{c}{2001} & $\%$ & \multicolumn{1}{c}{2007} & \multicolumn{1}{c}{$\%$} & 2011 (at 1994 prices) & \multicolumn{1}{c}{$\%$} \\
\hline Food products and beverages & 23.2 & Food products/beverages & 19.83 & Food products/beverages & 19.07 \\
Mining/quarrying & 6.8 & Non-metallic mineral products & 5.33 & $\begin{array}{l}\text { Non-metallic mineral } \\
\text { products }\end{array}$ & 7.81 \\
$\begin{array}{l}\text { Motor vehicles; trailers/semi- } \\
\text { trailers }\end{array}$ & 5.3 & Fabricated metal products & 5.18 & Metal products & 5.90 \\
Chemicals/chemical products & 4.8 & Transport equipment & 5.04 & Rubber/plastics & 4.92 \\
Textiles & 4.6 & Chemicals/chemical products & 4.79 & Leather & 4.59 \\
Leather & 4.0 & Textiles & 4.42 & Transport equipment & 4.50 \\
Rubber/plastics & 3.5 & Basic metals & 4.33 & Garments & 4.33 \\
Non-metallic mineral products & 3.3 & Garments & 4.26 & Chemicals/chemical products & 4.04 \\
Garments & 3.1 & Electrical equipment & 4.12 & Textiles & 4.03 \\
Basic metals & 2.9 & Rubber/plastics & 4.09 Computer. electronic/optical & 3.93 \\
Electrical equipment & 2.9 & & & products & \\
\hline
\end{tabular}

Source: GSO.

To mention some impressive examples, the analysis shows that in 2005 , there were only 82 metalmineral mining companies, but by 2009 this had jumped to 195 (an increase equivalent to 237.8 per cent). The number of enterprises in the coal and mining industry also increased from 56 up to 149 (266.1 per cent) during the same five years. But this positive development was mainly derived from increased demand rather than a breakthrough in technological innovation or enhanced position in the value chain. New entry of firms in textiles and garments, and wood and wood-related products has boosted the contribution of these sectors to total exports, bringing the two product groups into first and sixth place as Vietnam's top exporters, respectively. But these industries remain relatively uncompetitive, absorbing significant amounts of resources and labour. Once resources run out or the low-waged labour competitors in other developing countries emerge, Vietnam's competitiveness will be undermined.

Moreover, it needs to be mentioned that, thanks to deregulation and market liberalization process under WTO entry, the enterprises in the industrial sector and the economy as a whole have grown at annual rates of 17.2 per cent and 21.9 per cent and multiplied by $188.1 \%$ and $120.3 \%$ from $2005-09$, respectively. Thus, a direct link does not always exist between the increasing number of new companies and successful growth, or between new entrants and structural change within industrial sectors. For example, in 2005 there were five oil and gas exploration companies, and just eight in 
2006-09. Furthermore, the export value of crude oil declined over the same period, but this is not the whole story as exports has shifted from crude oil to domestically refined petroleum.

Figure 3: The growth rates of industrial gross outputs of high-speed growing sectors (at fixed 1994 prices)

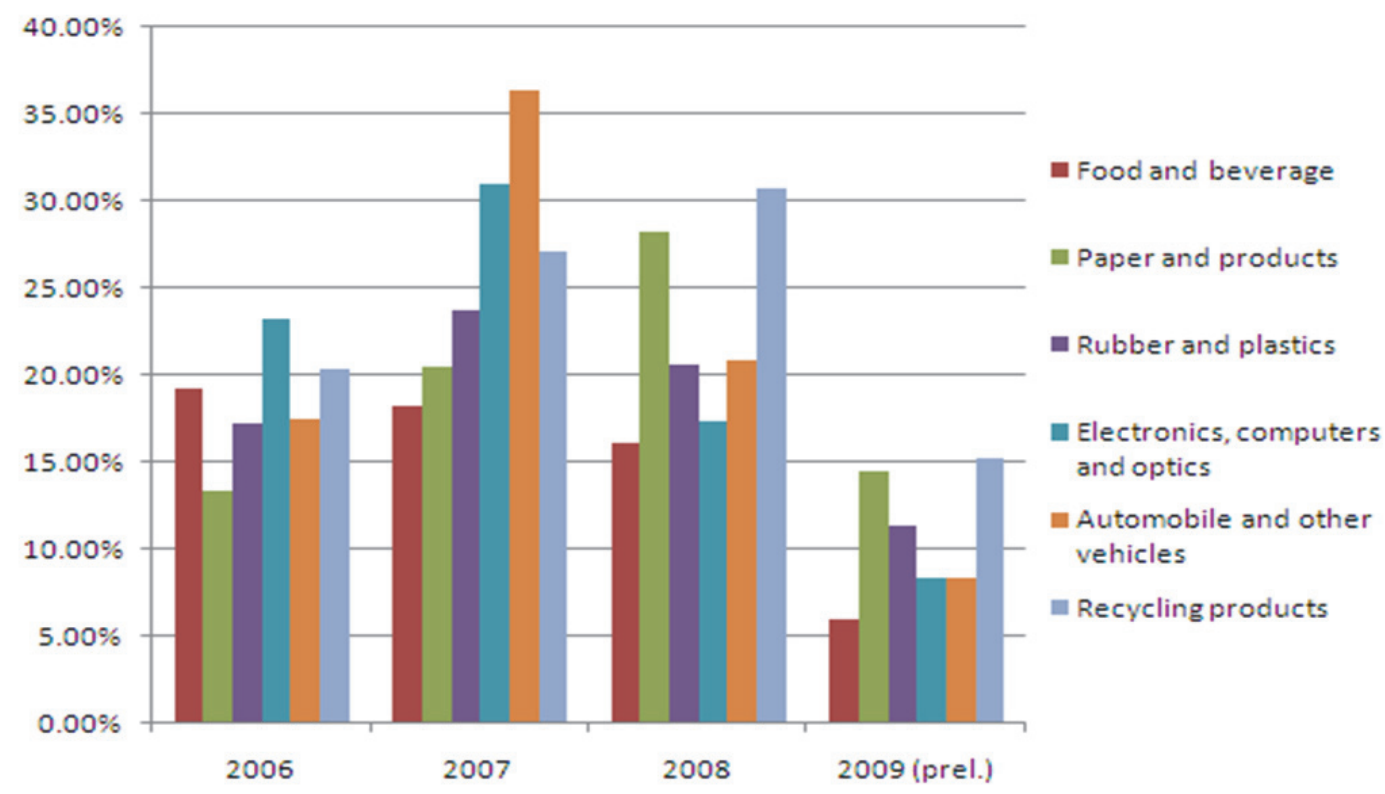

Source: GSO.

Figure 4: The growth rates of low-growth sectors (\%)

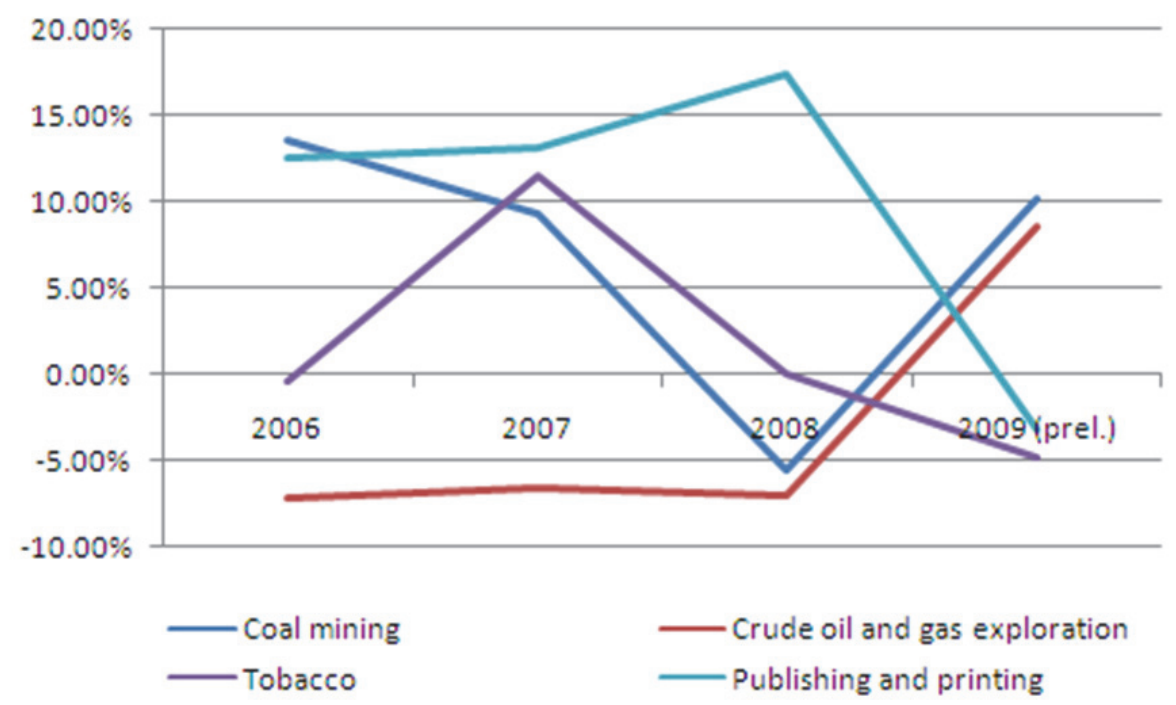

Source: GSO.

Thus we need to examine other export and production indicators, and define the sectors with above-average growth rates during this period as sunrise industries. Accordingly, food and beverages was still the largest and fastest growing sector (14.88 per cent per annum). Furthermore, output doubled in five sectors: recycling products, automobiles, electronics, computers and optics, paper and products, rubber and plastics. However, despite the accelerating rise of recycling products and 
metal-mineral mining (23.9 per cent and 13.62 per cent, respectively), their share in the industry's total value added is rather limited because of their very low starting positions.

In comparison during the same period, the coal mining sector grew, on average, only 6.88 per cent per annum; oil and gas even decreased -2.99 per cent per annum. Also lagging behind the average of the entire sector were tobacco (1.58 per cent) and publishing and printing (9.96 per cent).

Finally, since export-based growth is a key strategic goal for Vietnam, the performance of firms in this sector should be examined. In 2007, with the exception of the electronics and computer components, all of the top ten exports (valued in excess of US\$1 billion) were natural resourceintensive or labour-intensive products (i.e., low-level technology and added-values). By 2009, the garments industry (US\$9.06 billion) had overtaken crude oil (US\$6.19) in terms of value as the largest exporting sector.

Table 7: Top 10 major industrial export products, 2001-06 and 2007-11 (US\$, million)

\begin{tabular}{|c|c|c|c|c|c|c|}
\hline \multirow[t]{2}{*}{ Major products } & \multicolumn{6}{|c|}{ For the 2001-06 period } \\
\hline & 2001 & 2002 & 2003 & 2004 & 2005 & 2006 \\
\hline $\begin{array}{l}\text { Fish, crustaceans, molluscs and preparations } \\
\text { thereof }\end{array}$ & 1803.6 & 2030.5 & 2196.0 & 2400.3 & 2743.0 & 3350.4 \\
\hline Mineral fuels, lubricants and related materials & 3442.4 & 3547.6 & 4151.1 & 6233.3 & 8358.0 & 9709.4 \\
\hline Manufactured goods classified chiefly by materials & 982.3 & 1112.6 & 1342.9 & 1877.6 & 2154.9 & 2920.3 \\
\hline $\begin{array}{l}\text { Petroleum, petroleum products and related } \\
\text { materials }\end{array}$ & 3327.0 & 3391.5 & 3962.3 & 5879.0 & 7686.5 & 8792.7 \\
\hline $\begin{array}{l}\text { Petroleum oils and oils obtained from bituminous } \\
\text { minerals, crude }\end{array}$ & 3125.6 & 3270.0 & 3821.0 & 5670.6 & 7373.5 & 8312.0 \\
\hline Machinery and transport equipment & 1388.5 & 1319.1 & 1791.7 & 2561.0 & 3129.9 & 4186.1 \\
\hline Miscellaneous manufactured articles & 4375.0 & 5656.7 & 7225.7 & 9008.1 & 10403.1 & 12564.7 \\
\hline Articles of apparel and clothing accessories & 1867.4 & 2632.7 & 3466.7 & 4249.9 & 4680.6 & 5579.1 \\
\hline Footwear & 1630.2 & 1913.0 & 2299.2 & 2725.8 & 3078.6 & 3654.7 \\
\hline \multirow[t]{3}{*}{ Sport footwear } & 1144.5 & 1135.6 & 1127.3 & 1561.1 & 1367.6 & 1785.9 \\
\hline & \multicolumn{6}{|c|}{ For the 2007-11 period } \\
\hline & & 2007 & 2008 & 2009 & 2010 & 2011 \\
\hline Fishery & & 3763.4 & 4510.1 & 4255.3 & 5016.9 & 6112.4 \\
\hline Rucksacks, bags, pockets, wallets, hats & & 627.1 & 773.1 & 824.1 & 985.5 & 1384.8 \\
\hline Crude oil & & 8487.6 & 10356.8 & 6194 & 5023.5 & 7241.5 \\
\hline Plastic articles & & 709.5 & 933.7 & 867.4 & 1130.2 & 1359.9 \\
\hline Footwear & & 3999.5 & 4769.9 & 4071.3 & 5123.3 & 6549.3 \\
\hline Textiles, sewing products & & 7732.0 & 9120.5 & 9065.6 & 11209.8 & 14043.3 \\
\hline Wood and wooden products & & 2384.6 & 2767.2 & 2597.6 & 3444.5 & 3955.3 \\
\hline Foodstuff processed from starch and cereals & & 194.1 & 258.6 & 276.2 & 385.2 & 377.6 \\
\hline
\end{tabular}

Source: UN Comtrade.

In conclusion, Vietnam's sunrise industries are concentrated in subsections such as food and metalmineral mining, oil refinery, beverages, textiles and garments, wood processing, rubber and plastics, metallurgy, electronics/computers and optics, furniture, and recycling products. But in a developing 
country such as Vietnam where the every sector displays a strong upward trend from an original low base, it is hard to identify the true sunrise industries.

\section{The industrial policy framework}

\subsection{Macroeconomic policies}

Prior to the 1980s, the Vietnamese economy was essentially characterized by a traditional centrallyplanned economy, in which the means of production were owned by the state; physical input, output, and prices were administered by the government; there was no business autonomy and the factor markets were absent. Goods and services were highly regulated. In terms of banking and financial sector, a governmental mono-banking system and a passive financial system with no effective policies to mobilize domestic savings 4 resulted in household reluctance to save. Investment was financed mostly through external sources. By the end of the 1980s, industrial production had stagnated. The unbalanced goods-monetary supply which entailed a boost of credit and M2 growth 5 (by 1987: 43.38 times, 1988: 206.64 times) fuelled super inflation. By 1986, the consumption price index rose 774 per cent.

The reform or Doi Moi programme marked a turning point in policy, as it recognized the existence and essential role of a multi-ownership structure for Vietnam's economy. The re-engineering of policy included the removal of checks on internal trade, increased autonomy for the SOEs, and approval of the Law on Foreign Investment in 1987. In 1988, the functions of the central bank and commercials banks separated. In March 1989, Vietnam adopted a radical and comprehensive reform package aiming at stabilizing and opening the economy, and enhancing the freedom of choice for economic units and competition so as to fundamentally change the country's economic management system.

During the 1990s, the annual GDP growth rate averaged at 7.2 per cent and inflation was maintained at a single-digit level. This decade also experienced a new phase of industrialization, and there was a significant change in the sectoral structure of the economy.

In general, after comprehensive reform started in 1986, Vietnam's economic policies sought to promote high economic growth and, at the same time, to sustain macroeconomic stability. During the 2000s, economic growth had, nevertheless, relied heavily on expanding investment, but at the cost of investment efficiency. From 1990 to 2000, the contribution of capital to GDP growth was 34 per cent, increasing rapidly to 53 per cent from 2000 to 2008 (VCR 2010). Together with the rising global prices for energy and rice as well as the inflationary pressures created by the long period of investment- and credit-led growth, the vast increases in money supply triggered serious macroeconomic instability. By the fourth quarter of 2008, Vietnam started to suffer from the global financial crisis and economic downturn: exports growth languished and foreign direct inflows decreased. GDP growth fell from the 2007 peak to 6.3 per cent in 2008 and 5.3 per cent the following year. There was a slight economic recovery in 2010 when GDP growth achieved 6.78 per

\footnotetext{
4 Real deposit interest rates were negative.

5 A measure of the money supply, including money and quasi money.
} 
cent, but this upward trend could not be maintained. In 2011 the economy expanded only 5.89 per cent, and inflation rose to 18.1 per cent despite the very low credit growth of 12 per cent.

Table 8: Credit growth, inflation and GDP growth (\%)

\begin{tabular}{lcccccc}
\hline & 2006 & 2007 & 2008 & 2009 & 2010 & 2011 \\
\hline Credit growth & 24.8 & 53.9 & 23.4 & 37.6 & 27.65 & 12 \\
CPI & 6.6 & 12.6 & 19.9 & 6.52 & 11.75 & 18.13 \\
GDP growth & 8.23 & 8.46 & 6.31 & 5.32 & 6.78 & 5.89 \\
\hline
\end{tabular}

Source: GSO.

Table 8 also shows some weakness in the country's macro-policies, including the excessive credit growth, implying an escalation of money supply in the economy. Unfortunately, the added credit is said to have gone into real estate and to many of the less-than-efficient SOEs. The downfall of large SOEs 6 in association with the collapse in the real estate market generated serious problems for private companies and other manufacturing sectors, overturning the attempts at macro-stabilization in previous years.

\subsection{Trade policies}

\section{Prior to the Doi Moi reform}

Prior to the launch of Doi Moi, there had been almost no efforts to improve export and import policies and integration. The economy was effectively an autarchy after the war, and all available resources had been dedicated to recovering from the conflict. Foreign trade, in general, was the monopoly of the SOEs until 1989. The gradual change in trade policy in the post-Doi Moi period was evident in the elimination of quotas for most commodities in 1989. But these were still tightly controlled with licenses and quotas until normalized a decade later between 1998 and 2001.

The reform of Vietnam's trade policy, which was the cornerstone of the 1986 Doi Moi strategy, had two main objectives. The first objective was to make the transition from a centrally-planned to a market-based economy by: (i) liberalizing and linking domestic prices to world prices so that they would have a role in guiding resources; (ii) increasing the number of trading entities beyond the initial number of centrally-controlled foreign trade companies to avoid distortions in price signals through anti-competitive behaviour by monopoly SOEs or through the de facto quantitative restrictions; (iii) developing trade policy instruments such as tariffs, quotas and licenses; and (iv) and removing exchange rate distortions. This re-design of the trading system was inextricably linked with reform of the enterprise sector to allow indirect regulation through market prices to replace the direct regulation of enterprise outputs. The second objective was to promote export-oriented industries by redressing the anti-export bias embedded in the protectionist regime.

\section{The years 2001-05}

Significant changes in export and import regulations were introduced in the 2001-05 period, such as the gradual expansion of export and import privileges. With a few exceptions, this enabled enterprises to export all types of goods. Furthermore, the list of banned export and import goods

\footnotetext{
6 Including the shipping corporation group, VINASHIN, and the sea transportation group VINALINES.
} 
was extended to cover a five-year period (2001-05), thus replacing the earlier practice of lists being issued on an annual basis. In addition to the roadmap for removing import licenses, quotas on rice exports and fertilizer imports were abolished, and the regulation of the main enterprises trading in these items lifted. This created a clearer, regulatory framework for export and import.

Two main export-supporting policies were also issued by the government during the years 2001-05. According to the first measure, ${ }^{7}$ enterprises could benefit from two forms of medium- and longterm credit (investment loans, post-investment interest subsidies, and export credit guarantee) and short-term credit (short-term loans, bidding guarantee and contract guarantee). And, second, to encourage the export of agricultural products, a 'reward' or bonus (based on export value) was introduced in 1998 to major exporters of rice, coffee, pork, vegetables and fruits, cashew nuts, pepper, tea, peanut, handicraft, and plastic products.

\section{The years 2006-10}

Vietnam joined WTO in November 2006, gaining membership in January 2007. As a result, the country's policies and legal framework were aligned with those of the WTO. The Commercial Law, replacing the earlier 1997 version, was approved in 2005, and came into effect in 2006 when Decree $12 / 2006 /$ ND-CP was enforced. At the same time, regulations with regard to national treatment, protection, anti-dumping, anti-subsiding have influenced the country's comprehensive regulatory framework and significantly changed the administration of foreign trade activities. Trading rights have been expanded to all economic sectors, with a relaxation on foreign-invested enterprises and branches of foreign companies.

In compliance with WTO principles, the Vietnam Development Bank was re-organized from its previous incarnation 8 for making credit available for development and export. In addition, the government was committed to eliminating direct export support (including the exporting reward), and supported the implementation of trade promotion programme for advertising, promoting products in key markets, expansion and entry into new markets and diversification of the export market. ${ }^{9}$

WTO membership created new opportunities for Vietnamese firms to enter global markets at lower tariffs. This has put Vietnamese exports on an equal footing with those from other WTO members and has helped to increase its exports (Figure 5).

Yet, Vietnam's exports have been negatively affected by high domestic inflation and the global financial crisis since the mid-2008. The global recession led to a decline in world demand which, in turn, caused a fall in Vietnam's exports (-9.0 per cent). But exports recovered in 2010 more rapidly than projected. Totalling US $\$ 72.027$ billion, exports had increased by 26.3 per cent, surpassing the average 18.1 per cent rate for the years 2001-0, and exceeding the projected 15 per cent target set by the development strategy for the export and import of goods and services for this period.

\footnotetext{
7 Prime Minister's Decision 133/2001/QD-TTg on Credit Programme for supporting exports.

8 The Vietnam Development Fund.

9 Recently, Decision 72/2010/QD-TTg on 15 November 2010 on regulating the development, management and implementation of national trade promotion programme has been promulgated.
} 
In addition to agreements within WTO framework, export performance of the textiles/garments and aquaculture subsectors has been affected by other FTAs implemented by Vietnam. 10 In general, changes in trade policies during the last two decades were facilitated by an integration process. As a result, industrial policy has been redirected towards promoting the country's export industries.

Figure 5: Vietnam's export values from 1990-2010 (million, US\$)

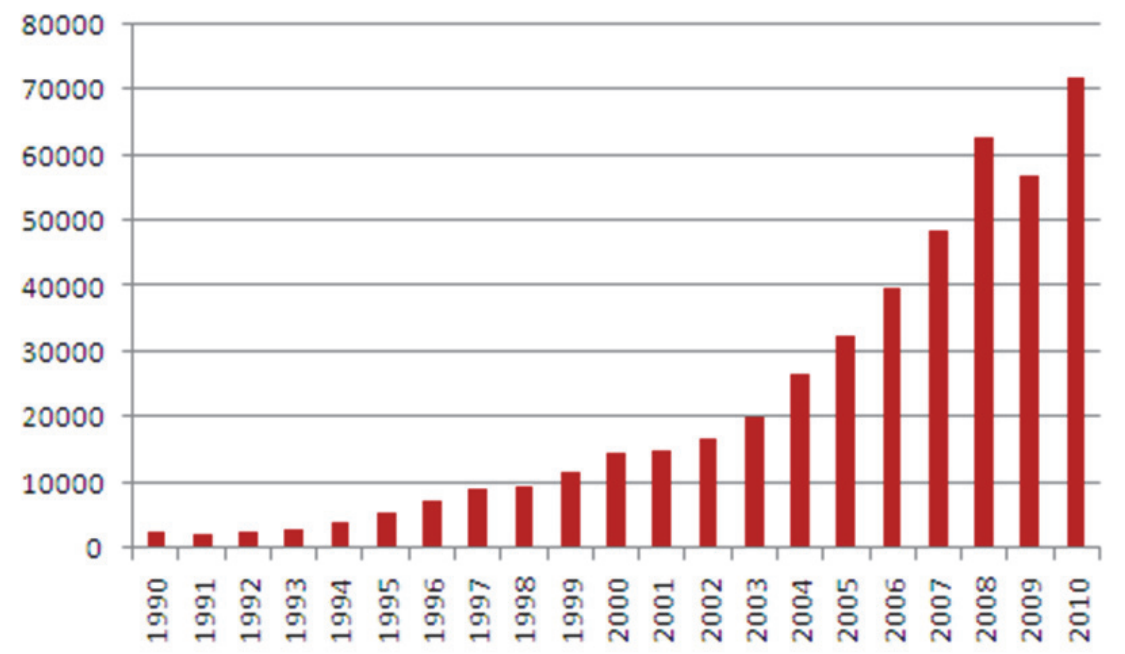

Source: GSO.

Figure 6: Annual growth rate of exports and GDP (\%, 2001- 2010)

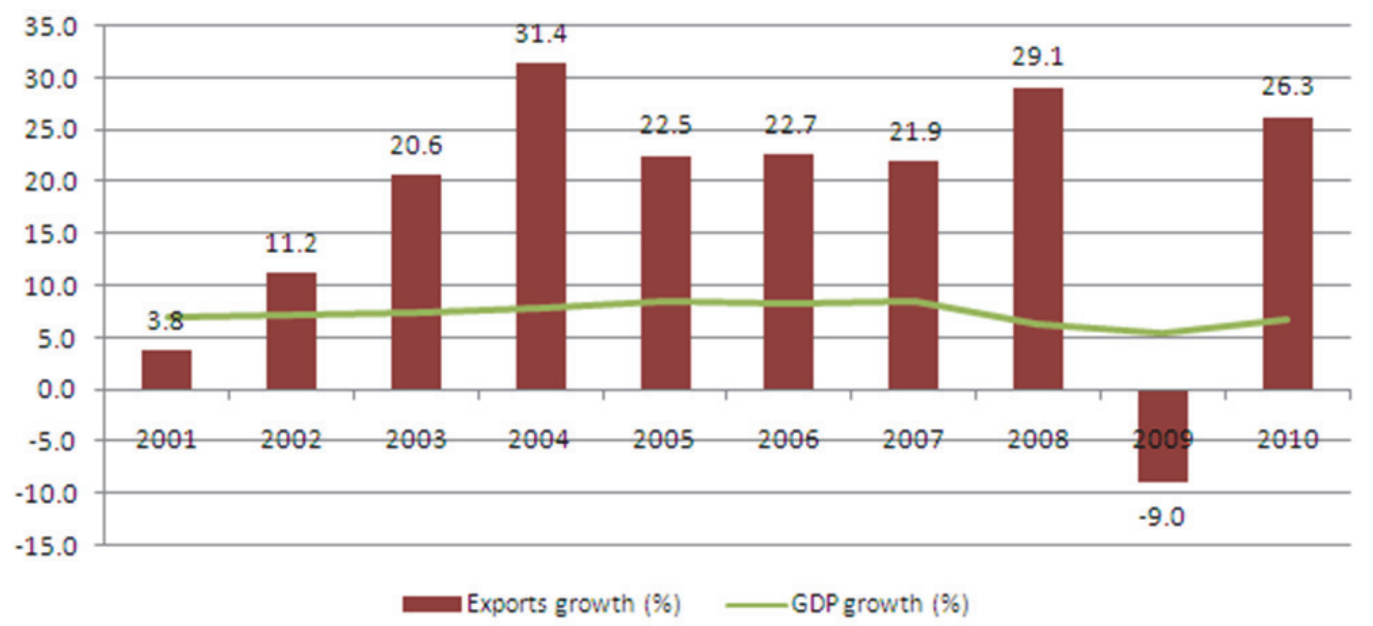

Source: GSO.

10 The following FTAs were signed mainly in the framework of the Association of Southeast Asian Nations (ASEAN), including the ASEAN-China Free Trade Agreement (ACFTA), the ASEAN-Korea Free Trade Agreement (AKFTA), Agreement on ASEAN-Japan Comprehensive Economic Partnership (AJCEP), and the ASEAN-Australia-New Zealand Free Trade Agreement (AANZFTA). In addition, Vietnam signed the Vietnam-Japan Economic Partnership Agreement (VJEPA) which may affect textile and garment export performance to Japanese markets. 


\subsection{The institutional and regulatory framework}

Vietnam's industrial policy framework is governed by a national Socioeconomic Development Strategy (SEDS) projected for a ten-year period.11 This is complemented with a five-year socioeconomic development plan (plan) as well as sectoral and industrial strategies and master plans. The Ministry of Industry and Trade is responsible for conducting and supervising industrial strategies and plans, while the Ministry of Planning and Investment undertakes the implementation of five-year plans articulated within the SEDS and investment policy, including coordination with the private sector through its Foreign Investment Agency (FIA), Enterprise Development Agency and Department of Economic Zones.

During 1991-95, the main objective of the industrial policy was to facilitate structural change, particularly for key sectors and regions. The two main key sectors being singled out in the five-year plan were heavy industry and natural resource exploitation, particularly crude oil, electricity, manufacturing, construction material, oil refinery, fertilizer production. In addition, other goals included the development of the agricultural, forestry and fishery sectors in close coordination with the manufacturing sector; consumption goods production and labour-intensive and export-oriented industries. The 1991-95 plan also prioritized the construction of infrastructure and transportation networks, and the modernization of the post and telecom networks both domestically and internationally.

It is obvious that the 1991-95 plan embodied two conflicting policies; on one hand, priority was given to the development of heavy industries and some manufacturing sectors that mainly serve domestic demand, which was considered to justify protectionism for certain industries. But on the other hand, exports, particularly by the manufacturing sector, were encouraged. In this period, although the aim was to improve the export structure towards increasing the share of manufacturing sector, mining and exploitation industries, including crude oil, still constituted the main exports.

Investment, for achieving the industrial policy goals, was mobilized by the government through the SOEs, and after the revision of the foreign investment law in 1992, the government undertook some measures to attract and mobilize external resources.

The five-year plan for 1996-2000 outlined the projected economic development figures. The annual growth rate for agriculture-forestry and fishery sector was, on average, 4.5-5 per cent, 14-15 per cent for industry, 12-13 per cent for services. The structural shift that followed was mainly aimed at quickly increasing the share of industry in the economy.

The main objectives in this period were still focused on heavy industry with its goal of meeting domestic demand and exploiting natural resources, but with an added emphasis on some sectors such as steel and cements. Disbursement among sectors was not as widely spread as the previous plan. In addition, the development of light, mainly export-oriented, industries 12 was targeted because of Vietnam's comparative advantage with regard to lower labour costs. Manufacturing industries were pushed to develop the food processing industry and consumption production, with a

11 Vietnam had completed two SEDSs in the last two decades; SEDS covering the years 1991-2000 and the SEDS for 2001-10. The SEDS for the period 2011-20 was approved by the National Assembly in January 2011.

12 Producing such items as textiles and garments, footwear, paper production, and handicrafts. 
priority given to sugarcane. Agricultural sector policies were initially linked with processing industries in agriculture, forestry and fishery to reform industrialization within the rural economy. The upgrading and construction of new key infrastructure were pushed, particularly the development of telecommunications, tourism, and consultation services on technology, finance, audit, banking and insurance.

A new reform of this period was the introduction of the Public Investment Programme (1996-2000) to implement certain industrial development goals. In addition to state investment, the government sought to attract private investment through regulatory revisions to the Law on Enterprises in 1999, and Law on Encouragement of Domestic Investment in 1998. In 2000, foreign investment policies were amended to create more favourable conditions for investors, as reflected in the Revised Foreign Investment Law.

In addition, the development of the EPZs and IZs proposed in 1996 was regarded as an important tool for achieving the goals of industrial policies, as these would conveniently provide the necessary infrastructure for new industries. In other words, the 1996-2000 plan basically relied on the previous plan but had greater focus. The most prominent feature in the 1996-2000 plan was the change in its approach: industrial clustering and sectors which could generate more jobs were encouraged. The government also placed greater reliance on market instruments such as tax and credit policies to attain targets rather applying the administrative instruments of the earlier eras.

The Socioeconomic Development Strategy (SEDS) for the years 2001-10 sought to achieve the country's 10-year development targets through the acceleration of growth and development, improvements in quality both quantitatively and qualitatively, and a strong emphasis on the efficiency and sustainability of growth and development. These objectives guided Vietnam's strategy, as implemented according to the two five-year plan: 2001-05 and 2006-10.

The 2001-05 plan continued the earlier policies geared to boosting economic structural change towards industrialization and modernization, by promoting the development of industry, encouraging the service sector and creating a linkage between agricultural advancement with rural economic development. Although protection was maintained for some industries, 13 it was more selective in terms of capital and technology. In addition, small and medium enterprises were supported through the SME promotion policy.

The government re-affirmed its policy orientation in the 2001-05 plan through such instruments as the second Public Investment Programme (2001-05) that enhanced the liberalization of foreign trade and investment (via Investment Law and Enterprise Law in 2005). Other instruments included investment in technology renovation, development of high technologies, and promotion of technology transfer via foreign investment.

Industrial policies in the 2001-05 plan had been revised from the two previous plans. Now there was a significant change in approach, with greater focus on small- and medium-enterprise development. But the sectors were widely diverse and thus failed to attract industries that could leverage the development of others. By 2001, 'The orientation of industrial development' document issued by the

13 Mining and oil industries, the metallurgical industry, cement, manufacturing mechanics, electronics and primary chemical industries. 
9th Vietnam Communist Party Congress identified 11 leading industries. 14 This was too many, and led to the dispersion of investment resources and low efficiency.

The goals outlined in the recent plan for the period 2006-10 included: (i) enhancing economic growth, increasing efficiency, sustainability and competitiveness of the economy; (ii) active integration and creating a breakthrough in international economic integration; and (iii) creating a favourable environment for entrepreneurial development. The target for economic structure during this period was 15-16 per cent for the agriculture-forestry-fishery sector, 43-44 per cent for industry and 40-41 per cent for the service sector. The agriculture-forestry-fishery sector is increasingly characterized by better quality, higher productivity and more competition. More attention was given to growing high value crops such as industrial crops or high-quality rice. In particular, the government has encouraged post-harvest preserving, the linkages between crops and foodprocessing as well as sustainable agriculture production. Because of the drive to preserve natural resources and protect the environment, the mining industries are gradually losing importance while the manufacturing industries continue to grow despite stronger competition in the wake of Vietnam's accession to WTO. Industrial plans have been revised to upgrade and improve the existing EPZs and IZs towards greater involvement of both domestic economic actors as well as foreign investors.

The XI National Congress of the Vietnam Communist Party (January 2011) approved the Socioeconomic Development Strategy for 2011-20 period. In addition to maintaining the vision of an industrialized Vietnam by 2020, the plan emphasizes knowledge-intensive industrial production and higher local content in products. Although heavy industries (mining, high-tech, defence, energy) and manufacturing industries are encouraged, support is limited to those competitively advantaged to be able to join higher positions in the global value chain. The document highlighted humanresources training as one of the three bottlenecks that need to be urgently addressed.

Most recently, the 3rd Session of the Party's Central Committee in October 2011 re-affirmed the need to restructure the economy. Over the coming five years, restructuring efforts will concentrate in three major areas-investment, financial market and the SOEs. In fact, governmental agencies in recent months have reviewed and redesigned relevant policies. As the anticipated spill-over effects from FDI rarely materialize and the decentralization of the licensing policy has opened the door for increasingly disadvantageous competition among provinces, the government is re-thinking its strategy: which sectors should be singled out for foreign investment and how to withdraw the excessively favourable incentives currently being offered to foreign investors. Similarly, the State Bank stipulated that by this year-end commercial banks are to cut financial sector credits by 16 per cent (especially real estates and stocks) to free capital for use by the manufacturing and services sectors.

\subsection{Sectoral specific policies}

In the 1960s, priority was given to heavy industry (VCPC 1960: 79) based on the argument that the vital goal of Vietnam at that time was to develop its defence industry in the face of the anti-

14 These included: agricultural processing, paper, textiles, leather and footwear, electronics, information technology and telecommunications, mechanical engineering, chemicals (chemical fertilizers), steel, gasoline, coal mining, and other mining. 
American war. However, 16 years later when reunification of the nation was complete, Vietnam continued to give precedence to heavy industry. But following the Doi Moi process, Vietnam launched three major economic programmes aimed at creating the necessary foundation for a modern industrial sector: food production, consumer goods and export goods. Investments in heavy industry and infrastructure were oriented to serve these three major economic programmes, with highest priority given to the electricity, coal, oil and gas industries.

In 1996, along with trade liberalization, Vietnam defined its key industries to include food processing, manufacturing consumer goods, export goods, electronics and information technology. In addition, the government continued sector policies to selectively develop certain heavy industry: energy and fuel; building materials; mechanical engineering; shipbuilding; metallurgy, and chemicals. In 2001 in the so-called 'Orientation of Industrial Development' document, Vietnam singled out 11 sectors as leading industries, considered to be vital for boosting the country's industrialization process. 15 Over the years 2001 to 2005, the government also approved a number of strategies on sector development based on the prioritized industries (see Appendix).

During this period a number of incentive policies and measures were formulated to implement the sector development strategies. These can be divided into five groups: (i) market-oriented policies, (ii) policy to mobilize resources, (iii) tax policy; (iv) R\&D policy; and (v) human resource development policy.

In general, sector-specific policies relied heavily on protectionism through financial incentives. But the over-enthusiastic identification of the key industries led to dispersed state investments in the context of low levels of accumulated public saving. As a result, after 20 years of Doi Moi, the favoured subsectors (automotive, machinery, information technology, sugar, etc.) have failed to achieve the anticipated outcomes, mainly because these favourites had not fitted the role of leading industries, and because some policy incentives had not succeeded as expected (Do Hoang Toan and Vu Trong Lam 2007).

The Prime Minister's decision (no. 55/2007/ QĐ-TTg) approving the list of priority industries and leading industries for 2006-10 was renewed with a number of incentive policies and measures. Accordingly, three key industries were defined for period 2007 to 2020. These included: (i) mechanical engineering (automobile, shipbuilding, complete equipment, agricultural machinery, mechatronics); (ii) electronic equipment, telecommunications and information technology; and (iii) products from new technologies (new energy, renewable energy, software, digital content).

In addition, seven sub industries were identified (including textiles, leather and footwear, plastic, agriculture-forestry-fishery processing, bauxite mining and processing, steel, and chemicals). Eventually, the plastic industry was dropped from the priority-industry list for 2011-15; and bauxite mining and processing and steel dropped from the 2016-20 list. The fact that the plastics industry has expanded quickly (with an average annual growth rate of 20-25 per cent during 2005-10) thus gaining an internationally competitive position without support, may account for its fall from the priority-industry list. The plastics industry accounted for 4.48 per cent of the total industrial output value of the whole country. Vietnamese plastic products are not only widely consumed on domestic markets but are also exported to 55 countries and territories. Many plastics firms in Vietnam have

15 Refer to footnote 12. 
gained recognition with prestigious trade marks (Hong Luc and Ma Phuong 2011). Sustainable development seems to have been the reason for removing bauxite mining and processing from the 2016-20 list of priority industries. Furthermore, it is assumed the steel industry's elimination from the 2016-20 priority-country list is based on the rational that its steel products lack the competitive advantage of countries with a long tradition of manufacturing these products (Vu Ngoc Lan et al. 2008).

Remarkably, the government provided a number of incentive policies targeted at two groups: (i) priority industries and (ii) leading industries. Government support to priority industries focused on three main areas: the provision of a production site, trade promotion support and R\&D activities. Production sites were allocated promptly to support new investment, expansion investment or intensive investment projects (including projects associated with relocating production). In terms of trade promotion, financial support was available for building and developing enterprise brand names and improving international quality-management standards (through industry associations). Moreover, enterprises in prioritized industries have been free to introduce products on the website of the Ministry of Trade and Industry, as well as display and introduce their products freely at trade fairs and exhibitions of national and local levels

Financial support to enterprises in the prioritized sectors was also forthcoming for R\&D-related activities. Central budget allocations have been directed towards: (i) efforts in technology transfers (including trial production under the technology transferred); (ii) strengthening the capability of scientific and technological bodies (laboratories, laboratory standards, R\&D institutions, etc.); and (iii) researching and adapting modern technology or equipment to improve productivity, quality and lower production costs. At the same time, funding from local-level budgets has been allocated for test-trial production (new products, materials and auxiliary materials to replace imports) before technology or equipment is utilized in mass production. Incentive policies for the priority industries have extended to all leading/key industries. In addition financial support has been provided to manufacturing projects aiming at environmental protection.

Generally speaking, Vietnam seems to have over-emphasized its efforts with the leading and prioritized industries. Most of these 5-10 page strategies were developed around 2002 and were included in projections extending to 2020-25 (see Appendix). The importance of the industrial sector is mirrored in these documents; these stipulate the products that comprise the sector, its quantitative production objectives and expected share of total export value by 2010-20. For example, the engineering industry was to account for 40-50 per cent of the total engineering demand by 2010 : of this, 30 per cent was to be exported. The automotive industry was to serve 80 of the domestic demand for standard cars, and have 60 per cent level of local content.

Nonetheless, sector-specific polices are inadequate for achieving the hoped-for goals, and offer little more than a list of the general instruments such as tax reductions, protective barriers, or encouraging calls for investment. Another weakness is that not all of the necessary components of a strategy are included, such as research-supported reasoning, comparative advantage-disadvantage assessments, resource- and demand-supply projections, and risk management. But most important, an overall strategy covering the nation's entire industry does not exist. Each industrial strategy is prepared by the relevant governmental agency specialized in that field, in consultation with the related business association. This induces a situation where each member believes his particular industry should be prioritized, with the ultimate result that too many sectors are targeted, impeding policy coherence. 
The government's strategy for information and communications sector (ITC) is generally considered to have been better designed with clear objectives, to be achieved through relatively detailed policy instruments and focused projects. An important success factor of the ICT industry is market liberalization. At present, ICT are markets competitive, with multiple ISPs, software and hardware vendors and several mobile phone networks. The use of computers and telecommunication devices is widespread and popular, and available at relatively low cost. Telecommunications currently is the only decreasing item in Vietnam's monthly consumer price index. Several Vietnamese ICT companies have invested actively in neighbouring countries as well as in Africa and Latin America.

The textile and garment industry is another success story. It has, in fact, has been among Vietnam's top five exports since 2001; in 2010, valued at US\$11.2 billion, it ranked as number one. But it is still very labour-intensive, and Vietnam is gradually losing its comparative advantage to other developing countries like Cambodia and Bangladesh. Efforts to lift garment exports to a higher position in the value-chain have not been successful so far. Presently, 60 per cent of the garment exporters are FDI companies.

The strategy for steel production is misaligned due to an inaccurate evaluation of the domestic market. At present, production capacity stands at roughly 9.0 million tons of (excluding 1.5 million tons from coming five big projects) of which 6.0 million tons goes to meet domestic demand. Moreover, steel imported from China and ASEAN is increasingly cheaper due to the Vietnam's economic integration commitments.

The Vietnamese mechanical engineering industry has been largely dependent on imported raw materials; major materials such as alloy steel, stainless steel and non-ferrous metals for machinery manufacture are all imported. For example, the shipbuilding industry needs to import vast amounts of solder but industries to supply intermediate products have not been developed. A central problem is the lack of transparency and poor management. VINASHIN, once considered the stalwart of the shipping industry, signed a number of underpriced contracts, 16 making it hugely unprofitable, and costing the state considerable amounts of cheap capital that had been invested in the firm (including government bonds, valued at US\$750 million). FDI companies are dominant in the motorbike markets, with yearly production increasing by 20 per cent. The strategy for the development of Vietnam's automotive industry up to year the 2010, with the projection up to 2020 is now considered a failure: no objectives have been achieved.

The electronics sector has been protected for more than 10 years, but like many other mechanical subsectors (automobile and shipbuilding), it still imports most components for domestic assembly.

Similarly, Vietnam's electricity supply has an impact on production throughout the country. The dry season can affect the capacity of the hydropower plants, particularly in provinces where many steelproduction FDI projects have been approved. The pace of equitization (or privatization) in power suppliers and retailers has been very slow. The electricity group of Vietnam (EVN) still controls most of the power markets. Its investment portfolio in diversified areas such as finance and real estates has been unprofitable, leading to insufficient capital for new power projects. Vietnam is currently an importer of electricity. Electricity prices tend to rise quickly over time, but according to EVN, they are still low. This makes private sector investments in the power sector unattractive.

16 In 2005, 53,000 dwt-grade ships for the UK, and 200,000 dwt for Vietnam's Petroleum Group, the PVN. 
Moreover, while the government's strategy for energy considers nuclear power a promising solution, this type of power source is increasingly controversial. The country has made no significant progress in developing and using alternative or renewable energy sources (other than hydroelectricity).

Table 9: Electricity price 2009-12 (US\$/kWh)

\begin{tabular}{ll}
\hline & Price, total (on average) \\
\hline 2009 & 5.26 cents \\
2010 & 5.43 cents \\
2011, February & 6.0 cents \\
2011, December & 6.3 cents \\
2012 & 6.6 cents \\
\hline
\end{tabular}

Note: Exchange rate quoted by the state bank of Vietnam by December every year. The price is excluded from Value added tax.

Source: Ministry of Industry and Trade.

\section{$4 \quad$ Patterns of industrial productivity}

\subsection{Industrial output per worker}

During the 2000-09 period, industrial output per worker in the manufacturing sector (at constant 1994 US dollars) increased on average 5 per cent per annum (from US $\$ 8,762$ per worker to US $\$ 13,593$ per worker, see Table 10). This trend has fluctuated over the past decade, with an acceleration in growth in the last six years. Indeed, while industrial output remained around US $\$ 9,000$ per worker from 2000 to 2003 , this figure rose, on average, 10 per cent each year from 2004 to 2009. Three major reasons can be cited to account for this surge: (i) higher domestic demand for manufactured goods due to improved quality; (ii) increasing manufactured exports after Vietnam's WTO accession; and (iii) renovation of the state-owned sector towards equitization and the dismantling of unsuccessful SOEs (GSO n.d.).

Both industrial output and the number of workers increased steadily in the manufacturing sector during the 2000-09 period, but at a different pace. Output expanded on average 16 per cent per annum (US $\$ 15$ billion in 2000 to US $\$ 56$ billion in 2009, at constant 1994 prices). The number of workers increased, on average, 11 per cent (1,597,431 workers in 2000 to 4,131,096 in 2009). The steady upward trend in both indicators is encouraging, given that the world economy has been severely dampened by the global financial crisis since 2008 .

Within the manufacturing sector, the highest average growth rate of industrial output per worker during 2000-09 was recorded for coke and refined petroleum products, attaining 19 per cent per annum. This rapid growth came from the sudden surge of industrial output in 2009, when the Dung Quat refinery started operations. Since then, industrial output value has risen dramatically (US $\$ 47$ million in 2008 to US\$420 million in 2009 and US\$780 million in 2010.

In contrast, during the same period, computers, electronics and optical products is the only manufacturing sector with a negative output growth rate per worker, averaging -2 per cent per annum. Although output value has risen, its growth rate lags behind the growth rate of workers. Within a single year (2009), output per worker dropped 20 per cent (from US $\$ 22,171$ per worker to US $\$ 17,710$ ) because large computer and electronics markets were negatively affected by the global 
crisis, reducing demand. In addition, the fact that the number of workers has grown faster than industrial output strengthens the view that electronics firms in Vietnam are engaged mostly in the labour-intensive and low value-added stages of production. The manufacture of computers, electronics and optical products, according to the OECD, is classified as a high-tech industry but based on the Vietnam's recent productivity, the country is currently unable to rely on high-tech industries for industrial productivity growth.

Table 10: Evolution of industrial output per worker by activities, 2000-09

\begin{tabular}{|c|c|c|c|c|}
\hline & \multicolumn{2}{|c|}{ Industrial output } & \multicolumn{2}{|c|}{ Industrial output per worker } \\
\hline & $\begin{array}{l}\text { Industrial output value, } \\
2009 \text { (in billions, } \\
\text { constant } 1994 \text { US\$) }\end{array}$ & $\begin{array}{l}\text { Growth of } \\
\text { industrial } \\
\text { output, } \\
2000-09(\%)\end{array}$ & $\begin{array}{c}\text { Industrial output per } \\
\text { worker in } 2009 \\
\text { (constant } 1994 \text { US\$ } \\
\text { per worker) }\end{array}$ & $\begin{array}{c}\text { Growth of } \\
\text { industrial output } \\
\text { per worker, } \\
2000-09(\%)\end{array}$ \\
\hline Manufacturing & 56.14 & 16 & 13,593 & 5 \\
\hline Food and beverage & 13.65 & 15 & 25,937 & 6 \\
\hline Textiles & 2.57 & 12 & 14,063 & 7 \\
\hline Apparel & 2.64 & 19 & 3,385 & 4 \\
\hline Leather & 2.57 & 14 & 4,199 & 5 \\
\hline Wooden prod. & 1.24 & 16 & 9,819 & 7 \\
\hline Paper and paper products & 1.34 & 16 & 15,548 & 5 \\
\hline Coke, refined petrol. products & 0.42 & 40 & 121,068 & 19 \\
\hline Chemical prod. & 2.98 & 13 & 34,136 & 9 \\
\hline Rubber and plastics products & 2.97 & 20 & 16,597 & 4 \\
\hline Non-metallic mineral products & 5.57 & 14 & 19,602 & 5 \\
\hline Metal and fabricated metal prod. & 5.56 & 20 & 19,638 & 4 \\
\hline $\begin{array}{l}\text { Computer, electronic and optical } \\
\text { products }\end{array}$ & 2.23 & 17 & 17,710 & -2 \\
\hline Electrical equipment & 2.17 & 23 & 17,430 & 9 \\
\hline Vehicles & 4.94 & 21 & 26,127 & 6 \\
\hline Furniture & 1.76 & 19 & 6,606 & 2 \\
\hline Mining and quarrying & 3.54 & 4 & 17,566 & 1 \\
\hline Electricity, gas, steam, water supply & 3.77 & 12 & 20,353 & 1 \\
\hline
\end{tabular}

Source: Calculation based on Statistical Yearbook of Vietnam 2006-10 (GSO).

\subsection{Net turnover per worker}

Net turnover per worker in the manufacturing sector increased from US\$10,592 per worker in 2001 to US $\$ 25,693$ per worker in 2009 (see Table 11). This trend has been stable throughout the period, recording an eight-fold increase in net turnover and a three-fold increase in the number of workers. Given the volatility of world economy during this period, the steady positive development is an encouraging sign. In addition, net turnover per worker of manufactured food and beverage in 2009 was nearly nine times that of the agricultural sector, reflecting the importance of the manufacturing sector for improving productivity. The electricity, gas, steam, water supply sector ranks first in terms of net turnover per worker during 2000-09 (rising from US\$18,890 in 2001 to US\$67,508 in 2009). The mining and quarrying sector had the second highest net turnover per worker in 2009 (reaching US $\$ 52,674 /$ per worker). Of the four industrial sectors, mining and quarrying was the only one experiencing a decline in net turnover in 2009 , due largely to weaker demand in the Chinese market. 
Nevertheless, neither sector can compare to the manufacturing sector in terms of net turnover and the number of workers. In 2009, the manufacturing sector employed over 4.1 million people, nearly eight times the combined figure of the mining/quarrying and electricity/gas/steam sectors. The manufacturing sector also generated nearly US\$106 billion in 2009, which was six times the combined figure of the two aforementioned sectors.

Manufactured chemicals and manufacture of coke, refined petroleum products recorded the largest average increase in net turnover per worker between 2000 and 2009 as well as the highest net turnover per worker in 2009. The figure for manufactured chemicals was US $\$ 97,064$, and that for manufacture of coke, refined petroleum products reached US\$272,664. Computers, electronics and optical products, on the other hand, experienced a decrease in net turnover per worker in the same period ( $\$ 42,772$ in 2001 to US $\$ 38,960$ in 2009 at current prices). Most of the firms in this sector are limited to assembly operations and are dependent on imported parts. Vietnam cannot compete in computers with China or other ASEAN countries in terms of price because of tariffs on imported components and the country's failure to increase local content. Given the current undeveloped supporting industries, if tariffs on computer parts/accessories are not reduced soon, it is possible that foreign-invested enterprises will re-locate operations to countries with lower costs. Domestic firms will struggle to maintain operations.

Table 11: Evolution of net turnover per worker by activities, 2001-09

\begin{tabular}{|c|c|c|c|c|}
\hline & \multicolumn{2}{|c|}{ Net turnover (US\$ billion) } & \multicolumn{2}{|c|}{ Net turnover per worker (US\$) } \\
\hline & 2009 & 2001 & 2009 & 2001 \\
\hline Manufacturing & 106 & 19 & 25,693 & 10,592 \\
\hline Food and beverage & 23 & 5 & 44,166 & 17,945 \\
\hline Textiles & 4 & 1 & 23,342 & 7,219 \\
\hline Apparel & 4 & 1 & 5,206 & 31,03 \\
\hline Coke, refined petrol. products & 1 & 0.1 & 272,664 & 93,100 \\
\hline Chemical products & 8 & 1 & 97,064 & 20,441 \\
\hline Rubber and plastics products & 7 & 1 & 37,728 & 13,020 \\
\hline Metal and fabricated metal products & 13 & 1 & 47,356 & 14,032 \\
\hline Computers, electronic and optical products & 5 & 1 & 38,960 & 42,772 \\
\hline Vehicles & 11 & 2 & 59,168 & 25,906 \\
\hline Furniture & 3 & 0.4 & 11,867 & 4,857 \\
\hline Mining and quarrying & 11 & 3 & 52,674 & 26,108 \\
\hline Electricity, gas, steam, water supply & 8 & 1 & 67,508 & 18,890 \\
\hline Construction & 20 & 4 & 1,4554 & 6,207 \\
\hline
\end{tabular}

Source: GSO.

\subsection{Net turnover per worker by industrial sector and ownership}

During 2004-08, manufacturing SOEs recorded the largest increase in net turnover per worker (US\$13,654 to US\$29,877). The steady increase in net turnover and a decrease in the number of workers implies increased worker productivity. Indeed, net turnover for the SOEs rose gradually from US $\$ 10$ billion in 2004 to US $\$ 12$ billion in 2008, while the number of workers went from 757,199 in 2004 to just 413,972 in 2008. This decrease was due to equitization efforts and dismantling of unsuccessful SOEs; for example, the number of manufacturing sector SOEs dropped from 1,247 in 2004 to 792 in 2008, with local SOEs accounting for 66 per cent of this decrease. 
Net turnover per worker in non-state enterprises in the mining and quarrying sector increased nearly 2.5 times during 2004-08 (US\$3,937 to US $\$ 9,454$ ). However, in terms of value, productivity of the non-state enterprises does not compare to that of FIEs. Indeed, net turnover per worker of nonstate enterprises in 2008 was US $\$ 9,454$ compared to US $\$ 812,327$ for the FIEs. Most of these FIEs are from China, established either as joint ventures with their Vietnamese counterparts or direct investments into the mining and quarrying sector. ${ }^{17}$ Most metallic and non-metallic minerals be exported to China where demand has been increasing dramatically.

Table 12: Evolution of net turnover per worker by sectors and ownership

\begin{tabular}{|c|c|c|c|c|c|}
\hline & & \multicolumn{2}{|c|}{$\begin{array}{c}\text { Net turnover from business } \\
\text { (US } \$ \text { billion) }\end{array}$} & \multicolumn{2}{|c|}{$\begin{array}{c}\text { Net turnover per worker } \\
\text { (US\$) }\end{array}$} \\
\hline & & 2008 & 2004 & 2008 & 2004 \\
\hline \multirow[t]{3}{*}{ Manufacturing } & State & 12 & 10 & 29,877 & 13,654 \\
\hline & Non-state & 18 & 11 & 9,878 & 9,716 \\
\hline & Foreign-invested & 41 & 16 & 24,181 & 17,083 \\
\hline \multirow[t]{3}{*}{ Mining/ quarrying } & State & 3 & 2 & 24,605 & 15,241 \\
\hline & Non-state & 1 & 0.2 & 9,454 & 3,937 \\
\hline & Foreign-invested & 8 & 4 & 812,327 & 582,415 \\
\hline \multirow[t]{3}{*}{ Electricity/gas/water } & State & 6 & 2 & 58,482 & 23,942 \\
\hline & Non-state & 1 & 0.01 & 21,696 & 1,334 \\
\hline & Foreign-invested & 1 & 0.1 & 606,821 & 154,638 \\
\hline \multirow[t]{3}{*}{ Construction } & State & 4 & 4 & 15,090 & 8,510 \\
\hline & Non-state & 11 & 3 & 11,818 & 5,716 \\
\hline & Foreign-invested & 1 & 0.2 & 53,331 & 23,751 \\
\hline
\end{tabular}

Source: GSO.

\subsection{Net turnover per worker by industrial sector and firm size}

In terms of firm size, small- and medium-sized firms in the manufacturing sector have higher net turnover per worker than large firms. In 2008, the highest average net turnover per worker (US\$33,877) was recorded for medium-sized firms (with 200 to 299 employees). But the largest increase in net turnover per worker (from US $\$ 13,273$ to US\$32,180) during 2004-08 was evident within micro firms with 5 to 9 employees. This shows the important role of small- and mediumfirms in the manufacturing sector and also implies that large manufactured firms have not been able to utilize economies of scale.

Mining and quarrying and electricity, gas, water supply are the two industrial sectors where large firms exhibit the highest net turnover per worker, attaining respectively US $\$ 183,000$ and US $\$ 213,000$ in 2008. Moreover, firms employing between 1,000-4,999 workers in the electricity/gas/water sector achieved the largest increase in net turnover per worker during 2004-08. The rapid growth of net turnover in this sector came mostly from the many hydroelectrically plants that were built during the period. Hydroelectricity investments since 2007 have become popular, reflecting the sector's high rates of return. For example, there are nearly 150 hydroelectricity projects

17 www.dautunuocngoai.vn/Ho-so-Cong-nghiep-khai-khoang-tai-Viet-Nam_tc_298_0_412.html 
currently being implemented or soon to be carried out in the central provinces of Quang Nam and Hue and the highland provinces of Kontum and Dak Nong. 18

Table 13: Industrial net turnover per worker by firm size

\begin{tabular}{|c|c|c|c|c|c|c|c|c|}
\hline \multirow[b]{3}{*}{ Firm size } & \multicolumn{2}{|c|}{ Manufacturing } & \multicolumn{2}{|c|}{ Mining/quarrying } & \multicolumn{2}{|c|}{ Electricity/gas/water } & \multicolumn{2}{|c|}{ Construction } \\
\hline & \multicolumn{2}{|c|}{$\begin{array}{c}\text { Net turnover per worker } \\
\text { (US\$) }\end{array}$} & \multicolumn{2}{|c|}{$\begin{array}{c}\text { Net turnover per } \\
\text { worker (US\$) }\end{array}$} & \multicolumn{2}{|c|}{$\begin{array}{c}\text { Net turnover per } \\
\text { worker (US\$) }\end{array}$} & \multicolumn{2}{|c|}{$\begin{array}{c}\text { Net turnover pe } \\
\text { worker (US\$) }\end{array}$} \\
\hline & 2008 & 2004 & 2008 & 2004 & 2008 & 2004 & 2008 & 2004 \\
\hline$<5$ & 25,635 & 14,416 & 17,272 & 4,953 & 10,121 & 1,143 & 20,726 & 8,700 \\
\hline $5-9$ & 32,180 & 13,273 & 15,151 & 7,811 & 12,969 & 826 & 18,666 & 10,352 \\
\hline $10-49$ & 24,363 & 13,400 & 11,333 & 5,080 & 14,302 & 4,445 & 14,302 & 6,795 \\
\hline $50-199$ & 29,090 & 16,385 & 73,027 & 36,389 & 84,420 & 7,938 & 12,727 & 7,557 \\
\hline $200-299$ & 33,877 & 15,559 & 32,483 & 4,636 & 16,666 & 5,589 & 13,575 & 8,319 \\
\hline $300-499$ & 28,059 & 14,987 & 14,727 & 7,049 & 26,120 & 8,827 & 14,424 & 6,668 \\
\hline $500-999$ & 25,635 & 14,860 & 14,605 & 7,557 & 135,145 & 37,278 & 14,121 & 7,494 \\
\hline $1000-4999$ & 20,423 & 12,638 & 24,060 & 18,226 & 212,839 & 13,527 & 12,545 & 7,494 \\
\hline$>=5000$ & 13,818 & 5,906 & 183,264 & 158,765 & 50,604 & 28,832 & 6,848 & 7,494 \\
\hline
\end{tabular}

Source: GSO.

\section{$5 \quad$ Emerging policy issues}

\subsection{The top three issues in the current industrial policy debate}

Vietnam has successfully implemented the programmes outlined in its Socioeconomic Development Strategy Plans for the period 2001-10. Yet, the economy is faced with insufficient quality improvement, slow shift in economic structure and little potential for current modality of growth. The industry sector has been the key driver of growth in Vietnam in the last decades, accounting for a larger share in GDP and employment, and the shift towards products with higher value added and technological content. Overall, Vietnam's industrialization strategy and industrial policy, however, seemed to place greater emphasis on achieving a high rate of economic growth and economic structural change rather than building up industrial competitiveness and new competitive industries for future growth, as illustrated in this paper.

Currently, Vietnam is launching a new Socioeconomic Development Strategy to cover the 2011-20 period. The plan strives to achieve three goals, including improvement of market-oriented institutions, infrastructure and human resources for industrialization and modernization. Since the overall goal of 2011-20 SEDS is to transform Vietnam into an industrialized country by 2020, the debate of the current industrial policy is now focused on three major issues.

First, industrial policy in the past has made little contribution to improving Vietnam's competitiveness, given that the share of the industry sector in GDP increased over time. However, the dual-nature of Vietnam's industrial sector is a weakness rather than a strength. The import-

18 www.tuoitre.vn/Chinh-tri-xa-hoi/Moi-truong/343699/Chi-chit-thuy-dien-o-mien-Trung.html 
substitution sectors have failed to grow and provide sufficient input for downstream industries, including export-oriented ones (e.g., textiles or chemical industries). Similarly, the export-oriented sector has had to rely heavily on imports, rather than input from domestic industries because of the absence of local suppliers and supporting industries. Furthermore, desired spillovers from FDI, particularly via technology transfer and linkages with domestic enterprises, have been rare.

Second, earlier industrial policies failed to facilitate change in firm structure and building of largesized private enterprises. Furthermore, facts on supporting policies (especially for exports) remained scattered among many different documents and were inconsistent, particularly the range and type of financial incentives and instruments used. Industrial policy also failed to stimulate enterprises to actively build partnerships as well as production linkages to reduce costs and improve productivity. Sectoral policy overemphasized specific sectors and products at the expense of improving the competitiveness of enterprises. And lastly, Vietnam's firm structure has remained relatively unchanged: while the number of newly established private firms increased steadily after the Enterprise Law 2000 took into effect, most are small or medium-sized enterprises.

Lastly, Vietnam still lacks a well-coordinated framework for industrial policy (sector specific policy, trade policy, macroeconomic policy and other policies). Individual sector strategies and plans are developed in isolation, without coordination. With regard to investment policy, there is no discrimination among sectors, with the exception of sectors with investment priorities. Moreover, while production projects and export-oriented sectors have access to preferential credit policy, the majority of beneficiaries are SOEs, rather than private enterprises.

\subsection{How are these issues to be addressed?}

Industrial development, as outlined in the 2011-20 SEDS, can only be achieved by restructuring industrial production (such as increasing technology, local content, linkages in regional and global production network; development of supporting industries and industrial clusters). But the SEDS has failed to provide adequate guidelines on sectoral strategies. Each development strategy and/or master plan sets out ambiguous targets/objectives and broad implementation measures without sufficient detail and feasibility assessments. Moreover, there is no industrial strategy extending beyond 2020 .

Vietnam is regarded as a relatively open economy following its WTO accession. Industrial policy should, therefore, aim to facilitate the productivity gain (for example, learning by exporting) from export activities rather than simply endorse export expansion for ensuring long-term growth of the economy. The policy is also expected to improve firm structure and build linkages between domestic and foreign-invested firms. This is an important point for Vietnam because the main beneficiary of past industrial policies has been the SOE sector which has enjoyed protectionist measures but remained relatively inefficient and uncompetitive.

\subsection{What is the preferred sequencing of the research programme to make the results relevant to policy?}

Vietnam's SEDS for the period 2011-20 strongly underscores an export-oriented strategy for improving the competitiveness at both aggregate- and firm-level. While the manufacturing sector has expanded at a high growth rate and made a considerable contribution to Vietnam's export and 
growth performance, the question of whether or not manufacturing firms could learn from exporting to increase productivity and competitiveness remains open.

\section{Acronyms}

$\begin{array}{ll}\text { ASEAN } & \text { Association of Southeast Asian Nations } \\ \text { BTA } & \text { bilateral trade agreement } \\ \text { EPZs } & \text { export processing zones } \\ \text { EZs } & \text { economic zones } \\ \text { FDI } & \text { foreign direct investment } \\ \text { FIEs } & \text { foreign invested enterprises } \\ \text { FTA } & \text { free trade agreement } \\ \text { ICT } & \text { information and communications technology } \\ \text { IZs } & \text { industrial zones } \\ \text { SOEs } & \text { state-Owned enterprises } \\ \text { SEDS } & \text { Vietnam's Socioeconomic Development Strategy } \\ \text { WTO } & \text { World Trade Organization }\end{array}$

\section{Appendix 1: Data sources}

Official documents from the Office of the Prime Minister

2001 Decision 133/2001/QD-T

2002 Decision No. 175/2002/QĐ-TTg

3 December 2001

Decision No. 186/2002/QĐ-TTg

26 December 2002

2004 Decision No. 177/2004/QĐ-T'Tg

5 October 2004

2007 Decision No. 51/2007/QD-TTg of Apr 12

12 April 2007

Decision No. 55/2007/QĐ-TTg

23 April 2007

Decision No.56/2007/QD-TTg

3 May 2007

Decision No. 75/2007/QD-TTg

28 May 2007

Decision No. 145/2007/QD-TTg

4 September 2007

2009 Decision No. 50/2009/QD-TTg

3 April 2009

2010 Decision 72/2010/QD-TTg

Other official documentation

1998 Decision No. 626/1998/QĐ-TCBĐ

5 October 1998

issued by the General Director of the General Post Office

2007 Directive No. 07/CT-BCVT

issued by the Minister of Post \& Telematics

2010 Decision 72/2010/QD-TTg

7 July 2007

2011 Decision No. 0391/QD-BCT

issued by the Minister of Industry and Trade

15 November 2010

24 January 


\section{Appendix tables}

Appendix Table 1: Index of industrial gross output at constant 1994 prices by industrial activity (\%)

\begin{tabular}{|c|c|c|c|c|c|c|}
\hline & 2006 & 2007 & 2008 & 2009 & 2010 & $\begin{array}{r}\text { Prelim } \\
2011\end{array}$ \\
\hline TOTAL & 116.8 & 116.8 & 113.9 & 108.5 & 115.7 & 113.5 \\
\hline Mining and quarrying & 98.6 & 98.1 & 96.6 & 109.2 & 101.1 & 102.5 \\
\hline Mining of coal and lignite & 113.6 & 108.9 & 94.6 & 107.8 & 104.6 & 102.0 \\
\hline Extraction of crude petroleum and natural gas & 92.9 & 93.5 & 93.1 & 109.0 & 93.1 & 101.0 \\
\hline Mining of metal ores & 132.3 & 118.7 & 97.4 & 106.2 & 140.1 & 95.7 \\
\hline Other mining and quarrying & 108.8 & 104.8 & 115.2 & 113.2 & 120.3 & 108.1 \\
\hline Mining support service activities & 247.6 & 88.9 & 243.0 & 75.4 & 235.1 & 115.2 \\
\hline Manufacturing & 119.1 & 118.8 & 115.3 & 108.1 & 116.7 & 114.2 \\
\hline Manufacture of: Food products & 118.0 & 118.7 & 115.2 & 107.6 & 114.2 & 117.9 \\
\hline Beverages & 124.1 & 117.0 & 121.4 & 104.4 & 103.0 & 110.4 \\
\hline Tobacco products & 99.6 & 111.6 & 100.1 & 104.9 & 109.3 & 109.9 \\
\hline Textiles & 124.4 & 107.0 & 105.9 & 105.4 & 114.5 & 114.3 \\
\hline Wearing apparel & 126.5 & 117.2 & 119.5 & 107.1 & 117.7 & 116.2 \\
\hline Leather and related products & 117.2 & 109.8 & 114.1 & 102.1 & 125.7 & 118.4 \\
\hline Wood/products of wood \& cork (except furniture) & 107.9 & 124.8 & 112.1 & 111.6 & 118.2 & 115.3 \\
\hline Paper and paper products & 113.3 & 120.5 & 128.2 & 101.7 & 115.5 & 117.5 \\
\hline Printing and reproduction of recorded media & 98.6 & 102.0 & 112.6 & 106.9 & 125.4 & 112.5 \\
\hline Manufacture of: Coke and refined petroleum products & 85.0 & 86.1 & 177.4 & 596.6 & 339.1 & 99.7 \\
\hline Chemicals and chemical products & 118.6 & 116.7 & 107.5 & 109.2 & 100.5 & 112.2 \\
\hline $\begin{array}{l}\text { Pharmaceuticals, medicinal, chemical/botanical } \\
\text { products }\end{array}$ & 127.0 & 115.3 & 116.9 & 114.2 & 148.7 & 125.8 \\
\hline Rubber and plastics products & 117.2 & 123.8 & 120.7 & 102.6 & 118.0 & 117.1 \\
\hline Other non-metallic mineral products & 118.2 & 108.6 & 112.6 & 114.9 & 107.3 & 108.9 \\
\hline Basic metals & 112.6 & 117.7 & 118.2 & 110.1 & 133.5 & 106.8 \\
\hline $\begin{array}{l}\text { Fabricated metal products (except machinery and } \\
\text { equipment) }\end{array}$ & 130.7 & 122.2 & 117.8 & 113.0 & 121.8 & 119.3 \\
\hline Computer, electronic and optical products & 118.4 & 135.6 & 119.0 & 106.3 & 124.3 & 118.2 \\
\hline Electrical equipment & 141.4 & 129.5 & 106.7 & 102.2 & 107.7 & 108.7 \\
\hline Machinery and equipment i.e. & 77.4 & 135.1 & 124.2 & 104.2 & 113.1 & 109.8 \\
\hline Motor vehicles; trailers and semi-trailers & 94.8 & 138.9 & 139.7 & 109.8 & 114.7 & 101.6 \\
\hline Other transport equipment & 129.6 & 137.2 & 115.4 & 105.8 & 105.3 & 114.6 \\
\hline Furniture & 137 & 116.7 & 108.6 & 103.3 & 120.4 & 114.3 \\
\hline Other manufacturing & 155.1 & 105.7 & 128.8 & 107.2 & 129.9 & 117.4 \\
\hline Repair and installation of machinery and equipment & 97.9 & 130.5 & 125 & 111.9 & 117.1 & 118.8 \\
\hline Electricity, gas, steam and air conditioning supply & 112.2 & 110.9 & 111.5 & 113.6 & 114.1 & 111.4 \\
\hline \multicolumn{7}{|l|}{ Water supply; sewerage, waste management and remediation } \\
\hline activities & 123.8 & 123.1 & 121.9 & 110.3 & 115.6 & 112.5 \\
\hline Water collection, treatment and supply & 111.7 & 104.5 & 114.2 & 100.6 & 110.7 & 111.5 \\
\hline Sewerage and sewer treatment activities & 195.2 & 103.3 & 178.7 & 126.4 & 106.4 & 105.7 \\
\hline Waste collection, treatment/disposal activities; materials recovery & 156.2 & 181.6 & 126 & 121.9 & 117.7 & 114.5 \\
\hline Remediation activities and other waste management services & & 127 & 176.6 & 83.7 & 848.2 & 120.5 \\
\hline
\end{tabular}

Source: GSO. 
Appendix Table A2: Structure of gross output of industry at current prices by province

\begin{tabular}{|c|c|c|c|c|c|c|}
\hline & 2005 & 2006 & 2007 & 2008 & 2009 & 2010 \\
\hline Whole COUNTRY & 100.00 & 100.00 & 100.00 & 100.00 & 100.00 & 100.00 \\
\hline Red River Delta & 21.66 & 22.53 & 24.48 & 24.73 & 24.12 & 23.96 \\
\hline Hà Nội & 7.77 & 7.66 & 7.91 & 9.08 & 8.72 & 8.07 \\
\hline Hà Tây & 1.34 & 1.33 & 1.38 & & & \\
\hline Vĩnh Phúc & 2.14 & 2.49 & 2.94 & 2.57 & 2.36 & 2.52 \\
\hline Bắc Ninh & 1.29 & 1.33 & 1.53 & 1.65 & 1.85 & 2.57 \\
\hline Quảng Ninh & 2.12 & 2.24 & 2.60 & 2.87 & 2.82 & 2.71 \\
\hline Hải Dương & 1.18 & 1.23 & 1.34 & 1.37 & 1.41 & 1.49 \\
\hline Hải Phòng & 2.55 & 2.73 & 2.95 & 3.10 & 2.81 & 2.58 \\
\hline Hưng Yên & 1.36 & 1.51 & 1.75 & 1.75 & 1.73 & 1.64 \\
\hline Thái Bình & 0.54 & 0.57 & 0.60 & 0.68 & 0.70 & 0.75 \\
\hline Hà Nam & 0.36 & 0.37 & 0.38 & 0.44 & 0.47 & 0.49 \\
\hline Nam Định & 0.67 & 0.73 & 0.77 & 0.80 & 0.80 & 0.71 \\
\hline Ninh Bình & 0.34 & 0.34 & 0.33 & 0.42 & 0.45 & 0.43 \\
\hline Northern midlands and mountain areas & 2.49 & 2.51 & 2.66 & 2.89 & 2.71 & 2.89 \\
\hline Hà Giang & 0.03 & 0.03 & 0.03 & 0.04 & 0.03 & 0.03 \\
\hline Cao Bằng & 0.06 & 0.06 & 0.06 & 0.07 & 0.06 & 0.08 \\
\hline Bắc Kạn & 0.03 & 0.03 & 0.03 & 0.02 & 0.03 & 0.03 \\
\hline Tuyên Quang & 0.07 & 0.07 & 0.07 & 0.07 & 0.09 & 0.08 \\
\hline Lào Cai & 0.08 & 0.13 & 0.13 & 0.21 & 0.18 & 0.21 \\
\hline Yên Bái & 0.10 & 0.10 & 0.11 & 0.13 & 0.14 & 0.15 \\
\hline Thái Nguyên & 0.73 & 0.75 & 0.91 & 0.89 & 0.78 & 0.84 \\
\hline Lạng Sơn & 0.07 & 0.08 & 0.06 & 0.08 & 0.08 & 0.07 \\
\hline Bắc Giang & 0.24 & 0.25 & 0.26 & 0.30 & 0.28 & 0.37 \\
\hline Phú Thọ & 0.87 & 0.80 & 0.79 & 0.85 & 0.77 & 0.76 \\
\hline Điện Biên & 0.04 & 0.04 & 0.04 & 0.04 & 0.05 & 0.04 \\
\hline Lai Châu & 0.01 & 0.01 & 0.01 & 0.01 & 0.02 & 0.02 \\
\hline Sơn La & 0.07 & 0.06 & 0.07 & 0.09 & 0.10 & 0.10 \\
\hline Hoà Bình & 0.09 & 0.10 & 0.09 & 0.09 & 0.10 & 0.10 \\
\hline North central area and central coastal area & 7.00 & 6.65 & 6.49 & 6.60 & 7.19 & 9.35 \\
\hline Thanh Hoá & 0.97 & 0.92 & 0.86 & 0.92 & 0.88 & 0.94 \\
\hline Nghệ An & 0.49 & 0.47 & 0.45 & 0.47 & 0.44 & 0.46 \\
\hline Hà Tĩnh & 0.15 & 0.15 & 0.16 & 0.16 & 0.17 & 0.16 \\
\hline Quảng Bình & 0.22 & 0.21 & 0.21 & 0.22 & 0.20 & 0.20 \\
\hline Quảng Trị & 0.10 & 0.10 & 0.11 & 0.12 & 0.12 & 0.11 \\
\hline Thừa Thiên Huế & 0.42 & 0.39 & 0.40 & 0.38 & 0.39 & 0.46 \\
\hline Đà Nã̃ng & 1.19 & 0.99 & 0.87 & 0.86 & 0.82 & 0.81 \\
\hline Quảng Nam & 0.47 & 0.53 & 0.63 & 0.66 & 0.69 & 0.70 \\
\hline Quảng Ngãi & 0.26 & 0.28 & 0.29 & 0.32 & 1.11 & 3.32 \\
\hline Bình Định & 0.64 & 0.62 & 0.64 & 0.61 & 0.57 & 0.56 \\
\hline Phú Yên & 0.27 & 0.26 & 0.29 & 0.28 & 0.32 & 0.29 \\
\hline Khánh Hoà & 1.35 & 1.29 & 1.14 & 1.15 & 1.08 & 0.95 \\
\hline Ninh Thuận & 0.11 & 0.10 & 0.09 & 0.11 & 0.08 & 0.08 \\
\hline Bình Thuận & 0.36 & 0.34 & 0.35 & 0.34 & 0.32 & 0.32 \\
\hline
\end{tabular}


Appendix Table A2: Structure of gross output of industry at current prices by province (continues)

\begin{tabular}{|c|c|c|c|c|c|c|}
\hline & 2005 & 2006 & 2007 & 2008 & 2009 & 2010 \\
\hline Central highlands & 0.73 & 0.75 & 0.75 & 0.78 & 0.78 & 0.77 \\
\hline Kon Tum & 0.04 & 0.05 & 0.06 & 0.05 & 0.06 & 0.05 \\
\hline Gia Lai & 0.16 & 0.17 & 0.20 & 0.23 & 0.24 & 0.23 \\
\hline Đắk Lắk & 0.22 & 0.22 & 0.21 & 0.21 & 0.22 & 0.25 \\
\hline Đắk Nông & 0.08 & 0.08 & 0.07 & 0.08 & 0.08 & 0.07 \\
\hline Lâm Đồng & 0.23 & 0.23 & 0.21 & 0.21 & 0.18 & 0.16 \\
\hline South East & 55.65 & 55.29 & 53.18 & 52.24 & 52.20 & 50.04 \\
\hline Bình Phước & 0.22 & 0.20 & 0.23 & 0.32 & 0.33 & 0.41 \\
\hline Tây Ninh & 0.54 & 0.57 & 0.61 & 0.60 & 0.62 & 0.71 \\
\hline Bình Dương & 8.06 & 8.37 & 8.91 & 9.25 & 8.86 & 8.71 \\
\hline Đồng Nai & 10.60 & 11.82 & 10.96 & 10.69 & 10.33 & 10.59 \\
\hline Bà Rịa - Vũng Tàu & 12.00 & 11.19 & 10.11 & 10.01 & 9.88 & 9.50 \\
\hline TP.Hồ Chí Minh & 24.23 & 23.14 & 22.36 & 21.37 & 22.18 & 20.12 \\
\hline Mekong River Delta & 8.84 & 8.89 & 9.23 & 9.85 & 9.97 & 10.05 \\
\hline Long An & 1.17 & 1.29 & 1.37 & 1.45 & 1.62 & 1.74 \\
\hline Tiền Giang & 0.63 & 0.62 & 0.63 & 0.65 & 0.66 & 0.82 \\
\hline Bến Tre & 0.35 & 0.32 & 0.30 & 0.30 & 0.32 & 0.30 \\
\hline Trà Vinh & 0.24 & 0.24 & 0.23 & 0.24 & 0.26 & 0.25 \\
\hline Vĩnh Long & 0.28 & 0.30 & 0.34 & 0.38 & 0.39 & 0.36 \\
\hline Đồng Tháp & 0.70 & 0.71 & 0.78 & 0.90 & 1.01 & 0.98 \\
\hline An Giang & 0.85 & 0.86 & 0.88 & 0.95 & 0.89 & 0.83 \\
\hline Kiên Giang & 0.71 & 0.72 & 0.70 & 0.69 & 0.66 & 0.64 \\
\hline Cần Thơ & 1.49 & 1.45 & 1.69 & 2.08 & 1.87 & 1.98 \\
\hline Hậu Giang & 0.38 & 0.33 & 0.34 & 0.32 & 0.29 & 0.27 \\
\hline Sóc Trăng & 0.50 & 0.61 & 0.52 & 0.50 & 0.53 & 0.46 \\
\hline Bạc Liêu & 0.28 & 0.29 & 0.29 & 0.27 & 0.28 & 0.29 \\
\hline Cà Mau & 1.26 & 1.15 & 1.16 & 1.12 & 1.19 & 1.12 \\
\hline NEC. & 3.63 & 3.38 & 3.21 & 2.91 & 3.03 & 2.94 \\
\hline
\end{tabular}

Source: GSO. 
Appendix Table A3: Development of minimum wages over time

\begin{tabular}{|c|c|c|c|}
\hline Year & Minimum wage & Sources & Date \\
\hline 1997 & VND 144,000 per month & & \\
\hline 2000 & VND 180,000 per month & Decree 10/2000/NĐ-CP () & 27 March 2000 \\
\hline 2002 & VND 210,000 per month & & \\
\hline 2003 & VND 290,000 per month & Government Decree 03/2003 & 15 Jan. 2003 \\
\hline 2005 & VND 350,000 per month & Decree 118/2005/NĐ-CP & 15 Sept. 2005 \\
\hline 2006 & VND 450,000 per month & Decree 94/2006/NĐ-CP & 7 Sept. 2006 \\
\hline 2008 & $\begin{array}{l}\text { VND } 540,000 \text { per month } \\
\text { Regional minimum wage within the FDI sector: } \\
\text { Region 1: VND } 1.0 \mathrm{~m} \text {. per month } \\
\text { Region 2: VND } 0.9 \mathrm{~m} \text {. per month } \\
\text { Region 3: VND } 0.8 \mathrm{~m} \text {. per month }\end{array}$ & $\begin{array}{l}\text { Decree 166, } 167 \text { and 168/2007/ND- } \\
\text { CP }\end{array}$ & 16 Nov. 2007 \\
\hline 2009 & $\begin{array}{l}\text { VND } 650,000 \text { per month } \\
\text { Regional minimum wage within the FDI sector: } \\
\text { Region 1: VND } 1.2 \mathrm{~m} \text {. per month } \\
\text { Region 2: VND } 1.08 \mathrm{~m} \text {. per month } \\
\text { Region 3: VND } 0.95 \mathrm{~m} \text {. per month } \\
\text { Region 4: VND } 0.92 \mathrm{~m} \text {. per month } \\
\text { Regional minimum wage for domestic enterprises: } \\
\text { Region 1: VND } 0.8 \mathrm{~m} \text {. per month } \\
\text { Region 2: VND } 0.74 \mathrm{~m} \text {. per month } \\
\text { Region 3: VND } 0.69 \mathrm{~m} \text {. per month } \\
\text { Region 4: VND } 0.65 \mathrm{~m} \text {. per month }\end{array}$ & $\begin{array}{l}\text { Decree } 33 / 2009 / \mathrm{ND}-\mathrm{CP} \text { for the } \\
\text { overall minimum wage } \\
\text { Decree } 110 / 2008 / \mathrm{ND}-\mathrm{CP} \text { and } \\
\text { Decree } 111 / 2008 / \mathrm{NE}-\mathrm{CP} \text { for the } \\
\text { regional minimum wages }\end{array}$ & $\begin{array}{l}6 \text { April } 2008 \\
10 \text { Oct. } 2009\end{array}$ \\
\hline 2010 & $\begin{array}{l}\text { VND } 730,000 \text { per month. } \\
\text { Regional minimum wage within the FDI sector: } \\
\text { Region 1: VND } 1.34 \mathrm{~m} \text {. per month } \\
\text { Region 2: VND } 1.19 \mathrm{~m} \text {. per month } \\
\text { Region 3: VND } 1.4 \mathrm{~m} \text {. per month } \\
\text { Region 4: VND } 1.0 \mathrm{~m} \text {. per month } \\
\text { Regional minimum wage for domestic enterprises: } \\
\text { Region 1: VND } 0.98 \mathrm{~m} \text {. per month } \\
\text { Region 2: VND } 0.88 \mathrm{~m} \text {. per month } \\
\text { Region 3: VND } 0.81 \mathrm{~m} \text {. per month } \\
\text { Region 4: VND } 0.74 \mathrm{~m} \text {. per month }\end{array}$ & $\begin{array}{l}\text { Decree } 28 / 2010 / \mathrm{NE}-\mathrm{CP} \text { on the } \\
\text { minimum wage } \\
\text { Decree } 97 / 2009 / \mathrm{ND}-\mathrm{CP} \text { on the } \\
\text { minimum wage for domestic } \\
\text { enterprises and Decree } 98 / 2009 / \mathrm{NE} \text { - } \\
\mathrm{CP} \text { on minimum wage for FDI sector. }\end{array}$ & 25 March 2010 \\
\hline 2011 & $\begin{array}{l}\text { VND 830,000 per month. } \\
\text { Regional minimum wage within the FDI sector: } \\
\text { Region 1: VND } 1.55 \mathrm{~m} \text {. per month } \\
\text { Region } 2: \text { VND } 1.35 \mathrm{~m} \text {. per month } \\
\text { Region 3: VND } 1.17 \mathrm{~m} \text {. per month } \\
\text { Region 4: VND } 1.10 \mathrm{~m} \text {. per month } \\
\text { Regional minimum wage for domestic enterprises: } \\
\text { Region 1: VND } 1.35 \mathrm{~m} \text {. per month } \\
\text { Region } 2: \text { VND } 1.20 \mathrm{~m} \text {. per month } \\
\text { Region 3: VND } 1.05 \mathrm{~m} \text {. per month } \\
\text { Region 4: VND } 0.83 \mathrm{~m} \text {. per month }\end{array}$ & $\begin{array}{l}\text { Decree 22/2011/ND-CP } \\
\text { Decree 107/2010/ND-CP and } \\
\text { Decree 108/2010/ND-CP for the } \\
\text { regional minimum wage. }\end{array}$ & $\begin{array}{l}4 \text { April } 2011 \\
29 \text { Oct. } 2010\end{array}$ \\
\hline 2012 & $\begin{array}{l}\text { Minimum wage is VND } 1,050,000 \text { per month } \\
\text { Regional minimum wage: } \\
\text { Region 1: VND } 2.0 \mathrm{~m} \text {. per month } \\
\text { Region 2: VND } 1.78 \mathrm{~m} \text {. per month } \\
\text { Region 3: VND } 1.55 \mathrm{~m} \text {. per month } \\
\text { Region 4: VND } 1.40 \mathrm{~m} \text {. per month }\end{array}$ & Decree 11/2011/ND-CP & 22 Aug. 2011 \\
\hline
\end{tabular}

Source: Collated by authors from various documents. 
Appendix Table A4: Structure of industrial gross output at constant 1994 prices by industrial activity and ownership (\%)

\begin{tabular}{|c|c|c|c|c|c|c|c|c|c|c|c|c|c|c|c|}
\hline \multirow[b]{2}{*}{ Industrial activity } & \multicolumn{3}{|c|}{2005} & \multicolumn{3}{|c|}{2008} & \multicolumn{3}{|c|}{2009} & \multicolumn{3}{|c|}{2010} & \multicolumn{3}{|c|}{2011} \\
\hline & State & $\begin{array}{l}\text { Non- } \\
\text { state }\end{array}$ & $\begin{array}{l}\text { FDI } \\
\text { sector }\end{array}$ & State & $\begin{array}{l}\text { Non- } \\
\text { state }\end{array}$ & $\begin{array}{l}\text { FDI } \\
\text { sector }\end{array}$ & State & $\begin{array}{l}\text { Non- } \\
\text { state }\end{array}$ & $\begin{array}{l}\text { FDI } \\
\text { sector }\end{array}$ & State & $\begin{array}{l}\text { Non- } \\
\text { state }\end{array}$ & $\begin{array}{l}\text { FDI } \\
\text { sector }\end{array}$ & State & $\begin{array}{l}\text { Non- } \\
\text { state }\end{array}$ & $\begin{array}{l}\text { FDI } \\
\text { sector }\end{array}$ \\
\hline Mining and quarrying & 20.08 & 7.97 & 71.95 & 26.85 & 11.70 & 61.45 & 23.85 & 14.03 & 62.12 & 26.68 & 15.48 & 57.85 & 26.57 & 16.47 & 56.96 \\
\hline Mining of coal and lignite & 94.39 & 3.56 & 2.05 & 96.61 & 2.00 & 1.39 & 95.82 & 3.36 & 0.82 & 94.40 & 2.75 & 2.84 & 94.32 & 2.66 & 3.02 \\
\hline Extraction of crude petroleum/natural gas & 0.11 & 0.00 & 99.89 & 1.93 & 0.00 & 98.07 & 0.52 & 0.00 & 99.48 & 1.15 & 0.00 & 98.85 & 1.16 & 0.00 & 98.84 \\
\hline Mining of metal ores & 59.56 & 37.51 & 1.79 & 55.39 & 33.23 & 11.38 & 48.22 & 39.22 & 12.56 & 35.98 & 43.69 & 20.34 & 36.16 & 47.42 & 16.42 \\
\hline Other mining and quarrying & 37.64 & 60.67 & 1.70 & 33.22 & 64.98 & 1.80 & 22.67 & 75.38 & 1.95 & 27.67 & 69.50 & 2.84 & 26.33 & 70.65 & 3.02 \\
\hline Mining support service activities & 0.00 & 100.00 & 0.00 & 6.71 & 77.77 & 15.60 & 9.90 & 63.80 & 26.30 & 72.91 & 15.57 & 11.53 & 72.91 & 15.69 & 11.37 \\
\hline Manufacturing of: & 30.69 & 33.20 & 36.11 & 20.17 & 38.40 & 41.43 & 19.16 & 38.99 & 41.85 & 18.57 & 38.55 & 42.88 & 18.14 & 38.23 & 43.64 \\
\hline - food products & 28.26 & 47.34 & 24.40 & 13.11 & 59.13 & 27.75 & 10.19 & 58.92 & 30.89 & 9.72 & 58.74 & 31.54 & 9.65 & 58.27 & 31.80 \\
\hline - beverages & 39.91 & 21.37 & 38.71 & 37.20 & 26.00 & 36.81 & 38.17 & 27.69 & 34.14 & 33.71 & 36.75 & 29.54 & 35.82 & 34.90 & 29.27 \\
\hline - tobacco products & 98.89 & 0.34 & 0.78 & 98.35 & 0.11 & 1.53 & 98.30 & 0.08 & 1.62 & 98.31 & 0.07 & 1.62 & 98.31 & 0.06 & 1.63 \\
\hline - textiles & 39.40 & 21.30 & 20.57 & 25.14 & 39.46 & 35.39 & 23.00 & 44.25 & 32.76 & 18.14 & 44.53 & 37.33 & 15.72 & 45.31 & 38.97 \\
\hline - wearing apparel & 24.90 & 38.25 & 36.85 & 10.01 & 45.32 & 44.68 & 8.31 & 42.95 & 48.73 & 8.19 & 44.03 & 47.78 & 8.44 & 43.12 & 48.44 \\
\hline - leather and related products & 10.60 & 29.97 & 59.43 & 5.61 & 27.67 & 66.72 & 3.29 & 26.39 & 70.33 & 2.08 & 22.45 & 75.47 & 1.75 & 21.40 & 76.85 \\
\hline - wood/products of wood/ (except furniture) & 12.65 & 69.50 & 17.85 & 8.01 & 79.29 & 12.70 & 7.86 & 80.14 & 12.00 & 6.61 & 79.76 & 13.63 & 6.57 & 79.29 & 14.14 \\
\hline - paper and paper products & 32.07 & 49.49 & 18.44 & 26.66 & 47.80 & 25.54 & 21.00 & 53.28 & 25.71 & 16.04 & 55.18 & 28.78 & 15.75 & 54.24 & 30.01 \\
\hline Printing and reproduction of recorded media & 77.52 & 14.75 & 4.78 & 59.97 & 26.93 & 13.10 & 55.10 & 26.68 & 18.22 & 60.48 & 24.32 & 15.20 & 63.25 & 21.65 & 15.10 \\
\hline \multicolumn{16}{|l|}{ Manufacturing of: } \\
\hline - coke and refined petroleum products & 0.00 & 37.16 & 6.68 & 1.74 & 34.12 & 64.14 & 80.24 & 7.41 & 12.35 & 92.45 & 3.51 & 4.04 & 93.88 & 4.59 & 4.68 \\
\hline - chemicals and chemical products & 37.21 & 3342.30 & 9399.50 & 29.21 & 16.97 & 53.82 & 24.66 & 18.71 & 56.64 & 25.93 & 24.70 & 49.37 & 27.30 & 26.15 & 46.55 \\
\hline $\begin{array}{l}\text { - pharmaceuticals, medicinal, } \\
\text { chemical/botanical products }\end{array}$ & 49.31 & 30.82 & 19.88 & 21.58 & 53.89 & 24.53 & 14.34 & 48.27 & 37.39 & 10.07 & 38.41 & 51.52 & 9.46 & 35.59 & 54.94 \\
\hline - rubber and plastics products & 20.08 & 50.87 & 29.04 & 11.96 & 49.61 & 38.43 & 12.08 & 51.06 & 36.87 & 11.52 & 48.94 & 39.54 & 11.48 & 48.17 & 40.35 \\
\hline - other non-metallic mineral products & 48.72 & 27.37 & 23.91 & 37.24 & 35.82 & 26.95 & 36.86 & 36.27 & 26.87 & 36.69 & 37.84 & 25.47 & 36.59 & 38.27 & 25.14 \\
\hline - basic metals & 38.64 & 27.14 & 34.22 & 21.50 & 46.10 & 32.40 & 20.87 & 49.13 & 30.00 & 21.24 & 43.52 & 35.24 & 23.60 & 40.08 & 36.32 \\
\hline $\begin{array}{l}\text { - fabricated metal products (exc. machinery } \\
\text { and equipment) }\end{array}$ & 12.47 & 51.90 & 35.63 & 14.21 & 44.71 & 41.08 & 13.68 & 47.67 & 38.65 & 12.88 & 46.22 & 40.90 & 12.84 & 46.40 & 40.77 \\
\hline - computer, electronic/optical products & 8.86 & 4.52 & 86.62 & 4.46 & 3.19 & 92.35 & 4.41 & 2.81 & 92.78 & 3.65 & 2.60 & 93.75 & 3.65 & 2.29 & 94.06 \\
\hline - electrical equipment & 40.14 & 12.04 & 47.82 & 26.58 & 17.45 & 55.96 & 30.99 & 14.58 & 54.43 & 26.03 & 16.59 & 57.37 & 26.49 & 15.39 & 58.12 \\
\hline - machinery and equipment i.e. & 22.88 & 34.95 & 42.17 & 12.84 & 41.79 & 45.37 & 13.00 & 42.93 & 44.07 & 10.82 & 45.19 & 43.99 & 10.89 & 42.52 & 46.60 \\
\hline - motor vehicles; trailers/semi-trailers & 13.52 & 7.29 & 79.19 & 10.39 & 14.90 & 74.71 & 9.85 & 14.39 & 75.76 & 10.64 & 13.31 & 76.05 & 11.74 & 12.48 & 75.79 \\
\hline - other transport equipment & 22.11 & 14.20 & 63.69 & 20.71 & 11.29 & 68.01 & 17.81 & 12.21 & 69.98 & 11.63 & 10.23 & 78.14 & 10.41 & 9.17 & 80.42 \\
\hline - furniture & 6.07 & 58.08 & 35.85 & 4.89 & 56.09 & 39.02 & 2.74 & 61.30 & 35.96 & 1.85 & 56.19 & 41.95 & 1.61 & 52.37 & 46.02 \\
\hline Other manufacturing & 7.18 & 22.43 & 70.39 & 3.49 & 24.20 & 72.30 & 3.10 & 22.45 & 74.44 & 2.89 & 21.01 & 76.10 & 2.97 & 18.15 & 78.88 \\
\hline Repair/installation of machinery/equipment & 5.12 & 42.83 & 52.06 & 47.26 & 38.31 & 14.43 & 34.67 & 38.89 & 26.44 & 37.28 & 36.07 & 26.66 & 36.37 & 36.80 & 26.82 \\
\hline
\end{tabular}


Appendix Table A4 (continues): Structure of industrial gross output at constant 1994 prices by industrial activity and ownership (\%)

\begin{tabular}{|c|c|c|c|c|c|c|c|c|c|c|c|c|c|c|c|}
\hline \multirow[b]{2}{*}{ Industrial activity } & \multicolumn{3}{|c|}{2005} & \multicolumn{3}{|c|}{2008} & \multicolumn{3}{|c|}{2009} & \multicolumn{3}{|c|}{2010} & \multicolumn{3}{|c|}{2011} \\
\hline & State & $\begin{array}{l}\text { Non- } \\
\text { state }\end{array}$ & $\begin{array}{l}\text { FDI } \\
\text { sector }\end{array}$ & State & $\begin{array}{l}\text { Non- } \\
\text { state }\end{array}$ & $\begin{array}{l}\text { FDI } \\
\text { sector }\end{array}$ & State & $\begin{array}{l}\text { Non- } \\
\text { state }\end{array}$ & $\begin{array}{l}\text { FDI } \\
\text { sector }\end{array}$ & State & $\begin{array}{l}\text { Non- } \\
\text { state }\end{array}$ & $\begin{array}{l}\text { FDI } \\
\text { sector }\end{array}$ & State & $\begin{array}{l}\text { Non- } \\
\text { state }\end{array}$ & $\begin{array}{l}\text { FDI } \\
\text { sector }\end{array}$ \\
\hline Electricity, gas, steam/air conditioning supply & 95.43 & 1.81 & 2.76 & 94.76 & 2.91 & 2.34 & 94.66 & 2.77 & 2.57 & 94.98 & 3.02 & 2.00 & 95.11 & 3.08 & 1.82 \\
\hline $\begin{array}{l}\text { Water supply; sewerage, waste } \\
\text { management/remediation activities }\end{array}$ & 81.34 & 14.61 & 4.05 & 77.08 & 20.65 & 2.27 & 71.20 & 21.91 & 6.89 & 67.69 & 25.70 & 6.61 & 66.25 & 27.33 & 6.41 \\
\hline Water collection, treatment/supply & 92.09 & 3.21 & 4.70 & 91.89 & 5.61 & 2.49 & 89.58 & 7.73 & 2.69 & 88.58 & 8.87 & 2.55 & 87.54 & 10.02 & 2.44 \\
\hline Sewerage/sewer treatment activities & 94.66 & 5.47 & 0.00 & 53.82 & 42.90 & 3.25 & 72.26 & 24.78 & 2.96 & 38.28 & 58.02 & 3.71 & 32.41 & 63.58 & 4.00 \\
\hline $\begin{array}{c}\text { Waste collection, treatment/disposal } \\
\text { activities; materials recovery }\end{array}$ & 35.48 & 62.29 & 2.23 & 60.52 & 37.71 & 1.77 & 48.83 & 38.19 & 12.98 & 48.31 & 39.42 & 12.27 & 47.59 & 40.67 & 11.74 \\
\hline $\begin{array}{l}\text { Remediation activities and other waste } \\
\text { management services }\end{array}$ & & & & 0.00 & 100.00 & 0.00 & 0.00 & 100.00 & 0.00 & 78.88 & 21.12 & 0.00 & 73.75 & 26.25 & \\
\hline
\end{tabular}

Source: GSO. 
Appendix Table A5: Major industrial products

\begin{tabular}{|c|c|c|c|c|c|c|c|c|c|c|c|c|c|}
\hline & Unit & 2000 & 2001 & 2002 & 2003 & 2004 & 2005 & 2006 & 2007 & 2008 & 2009 & 2010 & 2011 \\
\hline Coal & Tons ('000) & 11609.0 & 13397.0 & 16409.0 & 19314.0 & 27349 & 34093 & 38778 & 42483 & 39777 & 44078 & 44835 & 45824 \\
\hline Crude oil & Tons ('000) & 16291.0 & 16833.0 & 16863.0 & 17700.0 & 20051 & 18519 & _ 16800 & 15920 & 14904 & 16360 & 15014 & 15180 \\
\hline Frozen aquatic products & Tons ('000) & 177.7 & & & 361.6 & 485.6 & 681.7 & 801 & 815.6 & 1103.9 & 1177.8 & 1278.3 & 1399.1 \\
\hline Milled rice & Tons ('000) & 22225 & 23930 & 26950 & 27094 & 28459 & 28429 & 29655 & 30791 & 31786 & 33373 & 33473 & 34040 \\
\hline Beer & Litres, mm & 779.1 & 871.2 & 939.8 & 1118.9 & 1342.8 & 1460.6 & 1547.2 & 1655.3 & 1847.2 & 2007.5 & 2420.2 & 2650.6 \\
\hline Cigarettes & Packets, mm. & 2835.8 & 3075.2 & 3375.2 & 3870.6 & 4192.3 & 4484.7 & 3941.3 & 4549.1 & 4355 & 4833.7 & 5073.9 & 5454.9 \\
\hline Footwear & Pairs, mm. & 107.9 & 102.3 & 113.1 & 133.6 & 155.1 & 218.0 & 234.2 & 213.2 & 51.0 & 45.4 & 50.3 & 52.8 \\
\hline Fabric shoes & Pairs, mm. & 32.4 & 40.8 & 34.9 & 35.3 & 36.9 & 34.2 & 41.3 & 51.7 & 293.2 & 292.5 & 347.0 & 381.8 \\
\hline Sport shoes & Pairs, mm. & 109.219 & & & 189.795 & 215.868 & 240.79 & 271.761 & 286.871 & 293.2 & 292.5 & 347 & 381.8 \\
\hline Sawn wood & $\mathrm{m}^{3}\left({ }^{\prime} 000\right)$ & 1744 & 2036 & 2667 & 3291 & 3009 & 3232 & 4322 & 4441 & 5243.6 & 5672.2 & 5236.7 & 5125.6 \\
\hline Paper, cover & Tons ('000) & 408.5 & 445.3 & 489.6 & 687.4 & 809.3 & 901.2 & 1030.6 & 1727 & 1899.7 & 1752.3 & 1536.8 & 1593.9 \\
\hline Printed products & Pages, billion & 184.662 & 207 & 257 & 300.94 & 343.558 & 450.309 & 588.241 & 671.824 & 739.6 & 764.3 & 716.2 & 676.4 \\
\hline Chemical fertilizer & Tons ('000) & 1209.5 & 1270.4 & 1158.4 & 1294.3 & 1714.4 & 2189.5 & 2182.6 & 2499.4 & 2459.4 & 2360 & 2411.3 & 2396.8 \\
\hline Household porcelain & Pieces, mm. & 247.1 & 314.1 & 283.9 & 524.0 & 404.4 & 513.6 & 406.6 & 395.6 & 338.2 & 322.6 & 351.3 & 373 \\
\hline Cement & Tons ('000) & 13298 & 16073 & 21121 & 24127 & 26153 & 30808 & 32690 & 37102 & 40009 & 48810 & 55801 & 58994 \\
\hline Steel bars & Tons ('000) & 1803 & 1728 & 1565 & 1915 & 669.6 & 473.5 & 827.4 & 890.5 & 937 & 1702 & 2434 & 2354 \\
\hline Steel & Tons ('000) & 1583 & 1914 & 2503 & 2954 & 3279 & 3403 & 3837 & 4612 & 5001 & 6531 & 7910 & 7528 \\
\hline Printers & Pieces ('000) & & & & & & 672.5 & & & 8955.9 & 9420.5 & 14561.9 & 15907.1 \\
\hline Telephones & Pieces ('000) & & & & & & 168.6 & & & 3210.9 & 9120.9 & 9405.7 & 10906.2 \\
\hline Mobile phones & Pieces ('000) & & & & & & & & & 8.4 & 6362.5 & 37497.2 & 78323 \\
\hline Assembled TV sets & Pieces ('000) & 1013.1 & 1125.6 & 1597.3 & 2187.8 & 2659.7 & 2515.3 & 2445.6 & 2927.5 & 3106.7 & 3005.9 & 2800.3 & 3219.4 \\
\hline Digital cameras & Pieces ('000) & & & & & & & & & 3750.7 & 3158.7 & 3273 & 1307.7 \\
\hline Batteries $(1,5 \mathrm{~V})$ & Pieces, mm. & 128.6 & 269.8 & 264.4 & 328.7 & 359.5 & 395.7 & 277.3 & 342.8 & 330.4 & 393.2 & 397 & 405.4 \\
\hline Battery power & Kwh ('000) & & & & & & 8308 & & & 11083 & 11989 & 15931 & 16543 \\
\hline Household fridges/ freezers & Pieces ('000) & 174.5 & & & 479.3 & 621.5 & 692.6 & 793.4 & 946.1 & 1000.8 & 1306.8 & 1540.9 & 1204.1 \\
\hline Household washing machines & Pieces (‘000) & 159 & & & 283 & 514.5 & 336.6 & 339.8 & 414.5 & 532.2 & 491.4 & 467.4 & 679.9 \\
\hline Household electric fans & Pieces ('000) & 328.4 & 839.7 & 1072.0 & 1285.0 & 1088.6 & 1751.7 & 1809.6 & 2930.7 & 2914.7 & 5561 & 7174.1 & 7244.4 \\
\hline Air conditioners & Pieces ('000) & 52.5 & & & 72.1 & 127.3 & 147.9 & 189 & 284.5 & 313.1 & 325.2 & 343.7 & 350.8 \\
\hline Assembled automobile parts & Pieces ('000) & 13.547 & 21 & 30 & 47.701 & 50.954 & 59.2 & 47.576 & 71.892 & 104.8 & 112.5 & 112.3 & 107.9 \\
\hline Assembled motorbikes & Pieces ('000) & 463.4 & 610.3 & 1051.6 & 1180.4 & 1828.4 & 1982.1 & 2146.6 & 2729.2 & 2880.2 & 3091.5 & 3506.6 & 4208.5 \\
\hline Bicycles & Pieces ('000) & 659 & 1124 & 1583 & 2177 & 3607 & 2524.5 & 1591 & 1605 & 647.3 & 543.1 & 705.9 & 717 \\
\hline Electricity & Mill. kwh & 26683 & 30673.1 & 35888.0 & 40546 & 46202 & 52078 & 57917 & 64147 & 70960 & 80643 & 91722 & 101309 \\
\hline
\end{tabular}

Source: GSO. 
Appendix Table A6. Development strategy/plan of key industries and policies adapted over the period 2002-08

\begin{tabular}{|c|c|c|c|}
\hline Industry & Year & Objectives & Key policies/instruments \\
\hline Engineering & 2002 & $\begin{array}{l}\text { - } \quad \text { Serving } 45-50 \% \text { of domestic demand } \\
\text { - } \quad \text { Increasing exports to } 30 \% \text { by } 2010 \\
\text { Incl. complete equipment, motive driver, agricultural and processing machine and } \\
\text { instrument, construction, ship-building, electric-electronics, automobile. }\end{array}$ & $\begin{array}{l}\text { - Standardization } \\
\text { - Protection } \\
\text { - Favourable credit 3\%/per annum in } 12 \text { years } \\
\text { - Tax reduction }\end{array}$ \\
\hline Automobile & 2002 & $\begin{array}{l}\text { Standard vehicles: } \\
\text { - } \quad \text { Meeting } 40-50 \% \text { of domestic demand by } 2005 \text { and over } 80 \% \text { by } 2010 \\
\text { - } \quad \text { Ensuring } 40 \% \text { local content by } 2005 \text { and } 60 \% \text { by } 2010 \text { (especially, the localization } \\
\text { rate of engines to be } 50 \% \text { and of transmissions } 90 \% \text { ) } \\
\text { High-grade vehicles: travel vehicles produced by joint ventures: } \\
\text { - } \quad \text { Achieving localization rate of } 20-25 \% \text { by } 2005 \text { and } 40-45 \% \text { by } 2010 \text {, } \\
\text { - } \quad \text { Meeting } 80 \% \text { of domestic demand } \\
\text { High-grade trucks and buses: } \\
\text { - Ensuring a localization rate of } 20 \% \text { by } 2005 \text { and } 35-40 \% \text { by } 2010 \\
\text { Special-purpose vehicles: } \\
\text { - } \quad \text { Meeting } 30 \% \text { of domestic demand by } 2005 \text { and } 60 \% \text { by } 2010 \\
\text { - Ensuring local content of } 40 \% \text { by } 2005 \text { and } 60 \% \text { by } 2010\end{array}$ & $\begin{array}{l}\text { - Bringing auto engine production into the key industrial products programme } \\
\text { between now and } 2010 \\
\text { - Specific incentives about land, credits, technology transfer scientific research, } \\
\text { investment for projects of production of common and special-purpose vehicles }\end{array}$ \\
\hline Pharmacy & 2002 & $\begin{array}{ll}\text { - } & \text { Promoting application of good practice policy (GPP) } \\
\text { - } & \text { Meeting } 60 \% \text { of domestic demand } \\
& \text { Average consumption per head of US } \$ 12-15 / \text { year } \\
\text { - } & \text { Reaching a ratio } 1.5 \text { pharmacist per } 10.000 \text { people by } 2010 \\
\end{array}$ & $\begin{array}{l}\text { - General policies on investment, R\&D, human resources, training } \\
\text { - Placing priority on quality supervision, encouraging FDI } \\
\text { - Encouraging generic and traditional pharmacy. }\end{array}$ \\
\hline Electricity & 2004 & $\begin{array}{l}\text { - } \quad \text { Developing multi-source power (hydro, thermo, gas, wind, nuclear) } \\
\text { - } \quad \text { Constructing gas-electricity-fertilizer in the south, hydro-power plant in Son La } \\
\text { - } \quad \text { Attaining } 53 \text { bn. kWh by 2005: } 88-93 \text { bn kWh by 2010: 201-250 bn kWh by } 2020 \\
\text { - } \quad \text { Constructing hydro-power plants in all possible areas by 2020, total capacity: } \\
\text { 13-15,000 MW thermo-electric: adding 10,000 MW; Gas: 10,000 MW. } \\
\text { Exploring possibility to import electricity from Laos, Cambodia and China. }\end{array}$ & $\begin{array}{l}\text { - The EVN only invests in big projects over } 100 \mathrm{MW} \text {; creating conditions for firms of } \\
\text { other sectors to invest smaller projects } \\
\text { - No privatization plan for transmission network, power suppliers, retailing. }\end{array}$ \\
\hline Chemicals & 2005 & $\begin{array}{l}\text { Fertilizer } \\
\text { - NPK, intensive investment from various resources to reduce environmental pollution } \\
\text { Agricultural protection, Petroleum chemicals, industrial chemicals }\end{array}$ & $\begin{array}{l}\text { - Encouraging investment in all sectors } \\
\text { - Applying modern technologies, promoting economic restructuring } \\
\text { - Need favourable state incentives, regional development balance, tax and } \\
\text { investment policies }\end{array}$ \\
\hline
\end{tabular}




\begin{tabular}{|c|c|c|c|}
\hline Industry & Year & Objectives & Key policies/instruments \\
\hline ICT & 2005 & $\begin{array}{l}\text { - Encouraging wide application in key sectors, e-citizens, e-government, e-businesses to } \\
\text { bring to ASEAN region levels by } 2010 \\
\text { - } \quad \text { Generating ITC industry growth at } 20-25 \% / y e a r \text {, with a turnover of US } \$ 6-7 \text { bn by } 2010 \\
\text { - Creating a cheap, high-speed nationwide ITC network } \\
\text { Telephone coverage: } 32-42 / 100 \text { people, } 8-12 \text { Internet subscribers/100 people ( } 30 \% \\
\text { broad band) usage } 25-30 \% ; 10 \text { computers/100 people } \\
\text { Most intellectuals, } 50 \% \text { of pupils, } 30 \% \text { of the population use Internet }\end{array}$ & $\begin{array}{l}\text { - Developing e-citizens: } 80 \% \text { young people in urban areas } \\
\text { - Developing e-government: } 50 \% \text { documents, } 100 \% \text { agencies } \\
\text { - Developing e-businesses: } 50-70 \% \\
\text { - Developing e-commerce: } 25-30 \% \\
\text { - Developing software industry ( } 40 \% / y e a r) ; \text { hardware } 20 \% / y \text {; telecommunications } \\
\text { 22\%/y. } \\
\text { - Vietnamese-branded computers and mobile phones take over the market } \\
\text { - Infrastructure: } 100 \% \text { of villages, post-offices, institutions have access to Internet } \\
\text { - Policies of training and education, investment, taxation, R\&D, international } \\
\text { cooperation, market entry } \\
\text { - Focuses projects: Administrative simplifications, E-Vietnam, ITC application } \\
\text { projects in every fields, training, infrastructure }\end{array}$ \\
\hline $\begin{array}{l}\text { Motorbike } \\
\text { manufacturing }\end{array}$ & 2006 & $\begin{array}{l}\text { - } \quad \text { Meeting } 90 \% \text { of domestic demand by } 2010 \\
\text { - } \quad \text { Exporting } 450-500,000 \text { units or US } \$ 300 \text { million; establishing R\&D centres } \\
\text { - } \quad \text { Meeting } 95 \% \text { of domestic demand by } 2015 \\
\text { - } \quad \text { Achieving exports valued at US } \$ 500 \text { million by } 2015\end{array}$ & $\begin{array}{l}\text { - Standardization, and IP protection; ISO } 9001 \\
\text { - Encouraging joint-ventures between FDI and domestic firms; developing } \\
\text { international distribution channels } \\
\text { - Other general policies on labour, technology, finance }\end{array}$ \\
\hline Steel making & 2007 & 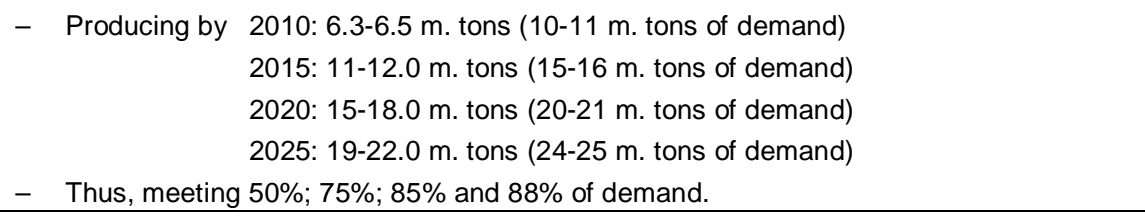 & $\begin{array}{l}\text { - 2007-15: Specifying } 7 \text { big projects/centres at traditional provincial locations and } \\
\text { projected investors: Ha Tinh, Dung Quat, Posco, India, Thai Nguyen, Lao Cai, } \\
\text { Vinashin } \\
\text { - Projected financial needs: } 2007-25 \text { : US } \$ 10-12.0 \text { bn } \\
\text { - Upgrading technology, human resources preparation, responsibility of ministries }\end{array}$ \\
\hline Energy & 2007 & 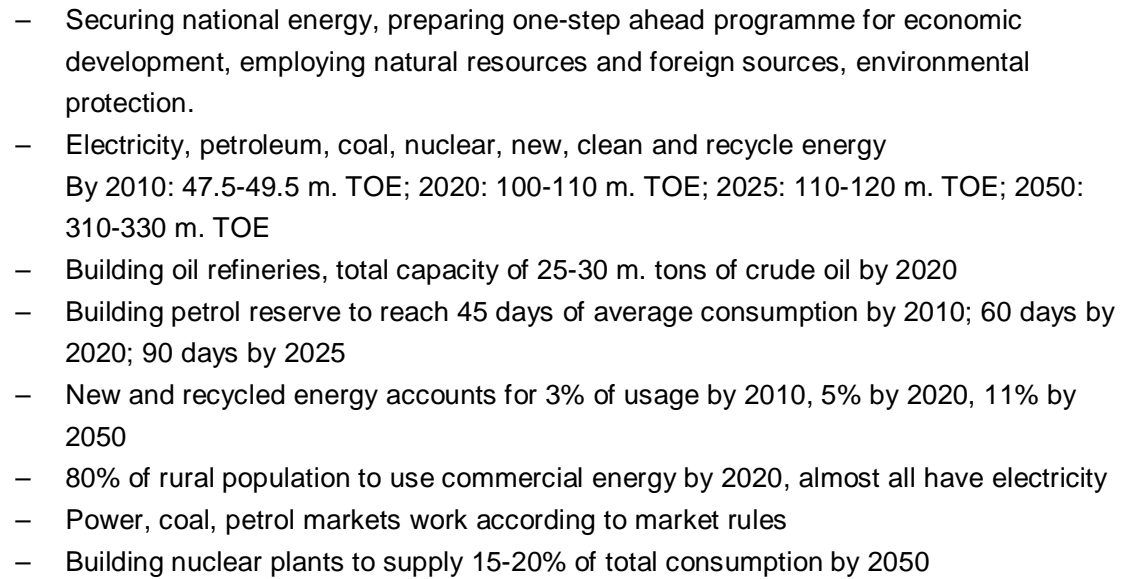 & $\begin{array}{l}\text { - Building hydro and thermo power plants } \\
\text { - Encouraging new and recycled energy } \\
\text { - Multi-ownership, attracting investment of all sectors } \\
\text { - Equitizing power plants and distribution } \\
\text { - Developing power markets } \\
\text { - Removing the public goods from businesses, but subsidizing remote areas } \\
\text { - Exploring deeper for coal in the north } \\
\text { - Employing petroleum gas } \\
\text { - Reducing the dependence on imported petrol } \\
\text { - Developing oil processing businesses } \\
\text { - General policies of energy security, reserves, environmental protection } \\
\text { - Policies of investment mainly based on three big State groups: PVN, EVN and TKV; } \\
\text { policies of international cooperation, ODA usage, finance and human resources }\end{array}$ \\
\hline
\end{tabular}


Appendix Table A6 (continues)

\begin{tabular}{|c|c|c|c|}
\hline Industry & Year & Objectives & Key policies/instruments \\
\hline Software & 2007 & 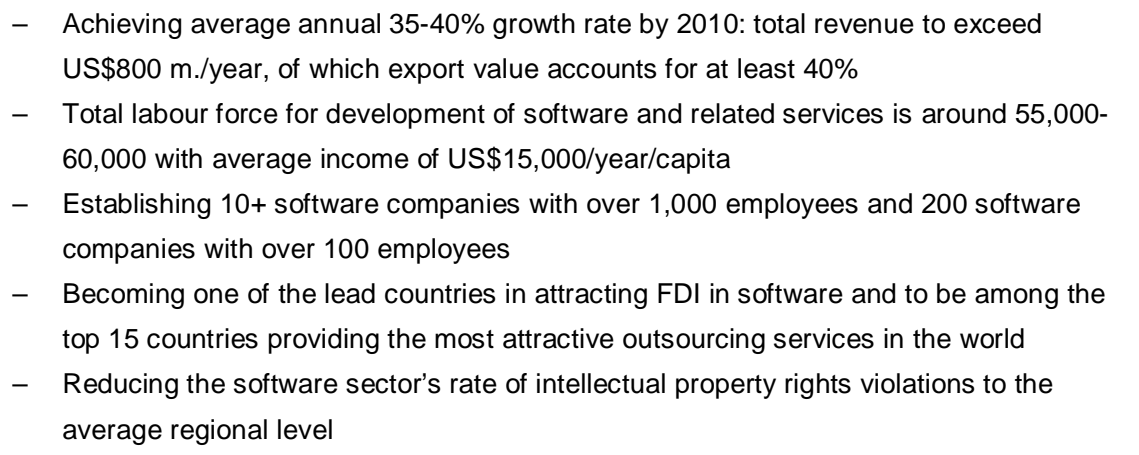 & $\begin{array}{l}\text { - Improving legal framework especially for intellectual property rights } \\
\text { - General policies of investment, finance, human resources, market } \\
\text { - Improving competitiveness } \\
\text { - Promoting application and development of open source software } \\
\text { - Developing telecommunication and internet infrastructure }\end{array}$ \\
\hline Digital content & 2007 & $\begin{array}{l}\text { - Achieve average } 35-40 \% \text { growth rate by } 2010 \text { : total revenue of US } \$ 400 \text { m year } \\
\text { - Developing 10-20 digital-content companies with over } 500 \text { workers } \\
\text { - Mastering basic technologies in the digital-content industry, producing a number of key } \\
\text { products which are competitive; establishing an online digital library system; developing } \\
\text { professional databases; providing effectively healthcare counselling and distance } \\
\text { learning services }\end{array}$ & $\begin{array}{l}\text { - Improving legal framework } \\
\text { - General policies on investment, finance, human resources, market, R\&D } \\
\text { - Developing digital content products and services (e-learning, e-banking) } \\
\text { - Developing telecommunication and internet infrastructure } \\
\text { - Enhancing safety, security and intellectual property }\end{array}$ \\
\hline Electronics & 2007 & $\begin{array}{l}\text { - } \quad \text { Generating US } \$ 4-6 \text { billion in production revenue by } 2010 \text {; } \\
\text { - } \quad \text { Generating export turnover of US } \$ 3-5 \text { billion, creating jobs for } 300,000 \text { workers } \\
\text { - } \quad \text { Striving for a growth rate of } 20-30 \% / y e a r\end{array}$ & $\begin{array}{l}\text { - Improving legal framework } \\
\text { - General policies on investment, industrial property protection, tax, finance, human } \\
\text { resources, market, technology, R\&D on key products } \\
\text { - Policy on supporting industries: Building capacity of essential processing industries } \\
\text { such as piercing metal parts, casting, plating, mould making within the programme } \\
\text { on development of supporting industries; accelerating the reform of the state } \\
\text { enterprises in mechanical engineering, plastics, cast to produce products for } \\
\text { supporting industries with a high level of specialization }\end{array}$ \\
\hline Coal mining & 2008 & $\begin{array}{l}\text { - } \quad \text { Assessing the reserve of }-300 \mathrm{~m} \text { in North East sink by } 2010 \\
\text { - } \quad \text { Assessing the reserve of Red River sink by } 2015 \\
\text { 2010: } 48-50 \mathrm{~m} \text {. tons; } 2015: 60-65 \mathrm{~m} . ; 2020: 70-75 \mathrm{~m} . ; 2025: 80 \mathrm{~m} \\
\text { - } \text { Diversifying coal products, liberalizing the coal markets, protecting the environment. }\end{array}$ & $\begin{array}{l}\text { - General policies on investment, technological improvement, pricing, human } \\
\text { resources. }\end{array}$ \\
\hline
\end{tabular}


Appendix Table A6 (continues)

\begin{tabular}{|c|c|c|}
\hline Industry & Objectives & Key policies/instruments \\
\hline Textile \& garments 2008 & $\begin{array}{l}\text { - Striving for an average production growth rate of: } \\
2008-10-16-18 \% / \text { year, exports } 20 \% \text { by } 2008-10 \\
2011-16-12-14 \% / y e a r, \text { exports } 15 \% / y e a r . \\
\text { - Improving local content } 50 \% \text { by } 2010,60 \% \text { by } 2015,70 \% \text { by } 2020 \text {. }\end{array}$ & $\begin{array}{l}\text { - Improving competitiveness, branding, packaging, fashion } \\
\text { - Developing supporting industries, securing materials } \\
\text { - Moving the plants to IZs, EPZs to protect environment, labour-intensive businesses } \\
\text { to rural areas } \\
\text { - Developing fashion markets in urban areas } \\
\text { - Developing cotton-material sources } \\
\text { - ISO14000, SA8000 } \\
\text { - General policies of investment, finance, human resources, technology, marketing, }\end{array}$ \\
\hline
\end{tabular}
trade promotion, branding

High-tech $2008 \quad-\quad$ Vietnam fundamentally becomes an industrial country with modern-orientation by 2020

applicants $\quad$ - Focusing in prioritized, leading industries, facilitating others and having high added-

- Development directions for industries: electronics, ICT, engineering, metallurgy, value: electronics, ICT, engineering, metallurgy, chemicals, food processing, energy

- Added-value in industrial production: $42-45 \%$ by 2020 chemicals, food processing, energy. Specifying what technologies or processes should be included in the industries

- Increasing the proportion of high-tech industries, investment on R\&D to increase from $0.2-0.3 \%$ at present to $3.5-5.0 \%$ by $2015,8-10 \%$ by 2020

- Technological renovation of equipment/machinery to increase from 8-10\% at present to $10-15 \%$ by $2015,20 \%$ by 2020

$\stackrel{\oplus}{\oplus}$

Mechatronics $2011 \quad$ - Increasing production value (real price):

US $\$ 3,100$ bn by 2015

US $\$ 8,200$ bn by 2025

- Increasing export value:

US $\$ 18-20 \mathrm{~m}$. by 2015 ,

US $\$ 60-65$ m. by 2025

- Common policies to encourage technological transfer, finance and investment.

Leading products

- Machine tools CNC: 20\% domestic demand by 2015 and 30\% by 2025

- Machinery and equipment for construction and transportation: 30\% domestic

demand by 2015 and $50 \%$ by 2005

- Mechatronics equipment for processing agricultural products: $75 \%$ domestic

demand by $2015 ; 90 \%$ by 2025

- Mechatronics consumption goods: $75 \%$ domestic demand by 2015; $90 \%$ by 2025

- Medical mechatronics equipment: 16\% domestic demand by 2015; $60 \%$ by 2025

Technology

- By 2015: Producing by the OEM method for a number of products

- By 2025: Producing by the OBM method

Investment capital

- By 2015: US\$125 m.

- In 2016-25: US\$134 m.

General policies of investment, market, scientific research and technology transfer, human resources, finance, sector management 



\section{Bibliography}

Bui Thi Thiem (2007). 'Several Issues of Vietnam's Industrial Structure'. National University Magazine-Economics and Law, 23: 88-95.

CIEM (Central Institute for Economic Management) (2009, 2010, 2011). Vietnam Economy in 2008-2010. Hanoi: Financial Publishing House.

CIEM and ACI (2010). Vietnam Competitiveness Report 2010. Available at: http://www.isc.hbs.edu/pdf/Vietnam_Competitiveness_Report_2010_Eng.pdf

CIEM (2010a). 'The Economic Impact of Global Integration to Vietnam Three Years after Joining W'TO'. CIEM Project Report. Hanoi: Central Institute for Economic Management.

CIEM and the Asia Foundation (2011). 'The Competitiveness of Exporting Firms in Vietnam: Evidence from the Garment, Seafood and Electronics Industries. A CIEM/Asian Foundation Report. Available at: www//asiafoundation.org/publications/pdf/1038 (in Vietnamese).

GSO (2011). Statistical Year book 2001-10. Hanoi: Statistical Publishing House.

Dang Phong (2005). History of Vietnam Economy from 1945-2000. Hanoi: Social Sciences Publishing House

Đo Hoang Toan, and Vu Trong Lam (2007). Leading Economic Sectors - Theoretical and Practical Issues. National Hanoi: Politics Publishing House.

Duc Tho (2011). 'Over-supply Threat of the Motor-Bike Industry'. VnEconomy, 30 October. Available at: www.vneconomy.vn (in Vietnamese).

Hong Luc, and Ma Phuong (2011). 'Conference on Plan for the Development of the Plastics Sector up to 2020 with a vision toward 2025'. 18 March. Available at: www.tapchicongnghiep.vn. (in Vietnamese).

Nguyen Manh Hung (2011). Several Ideas on Vietnam Industrial Development Strategy from 2011-2020. Industrial Review of Vietnam, 1 December.

Nguyen Xuan Dung (2008). 'Vietnam Industry in the International Integration'. Papers presented at the Third International Symposium on Vietnam. Hanoi: Social Sciences Publishing House.

NTP (2008). 'Orientation for the "Taking off" Strategy'. Available at: www.tapchibcvt.gov.vn (in Vietnamese).

Pham Huyen (2011). 'Economic restructuring and the second Doi Moi'. Available at: www.vietnamnet.vn (in Vietnamese).

Tran Tuyen, and Doan Tinh (2010). 'Industrialization, Economic and Employment Structure Changes in Vietnam during Economic Transition'. MPRA Paper 26996. Available at: www. mpra.ub.uni-muenchen.de/26996/1/MPRA_paper_26996.pdf

Tuan An (2011). 'The Contradictory of Supply-Demand in Steel-Making Industry'. Vietnam Law Magazine, 18 June.

UN Comtrade (United Nations) (n.d.). International Merchandise Trade Statistics.

Vietnam Communist Party (1960). The III Vietnam Communist Party Congress Documents. Hanoi: Truth Publishing House. 
Vietnam Communist Party (1977). Resolution of the IV Vietnam Communist Party Congress. Hanoi: Truth Publishing House.

Vietnam Communist Party (1996). The VIII Vietnam Communist Party Congress Documents. Hanoi: Truth Publishing House.

Vu Ngoc Lan, Phan Le Nga, Khong Van Tuyen, and Nguyen Viet Thang (2008). 'Steel Industry Analysis Report'. Available at: www.wss.com.vn, September. 